\title{
HANSÁGI ÁGNES \\ Kemény Zsigmond, a Pesti Napló, az „olvasási vágy” és egy drámai költemény
}

Hogy Kemény Zsigmond másfél évtizedes szerkesztői müködése a Pesti Naplót a legbefolyásosabb magyar politikai napilappá tette és neve elválaszthatatlanul összeforrott a magyar sajtónyilvánosságot közel kilenc évtizeden át meghatározó újságéval - a magyar sajtó- és irodalomtörténet olyan közhelyei, amelyeknek közmegegyezésre számot tartó igazságát aligha jutna eszébe bárkinek is elvitatni. Már 1855 júniusa előtt, amikor Kemény átvette a lap szerkesztését, ,,arculatépítőek” az írásai: ${ }^{1} 1852$ októberétől az Élet és irodalom, 1853 augusztusától a Szellemi tér cikksorozata akár a későbbi szerkesztő művelődési programjaként is volna olvasható. ${ }^{2}$ Volna olvasható, abban az esetben, ha a Pesti Napló Kemény által irányított másfél évtizedében másképpen alakult volna a lap szerkezete és funkciója.

Az átvétel pillanatában, 1855 nyarán, a Pesti Napló felépítése megfelel azoknak az elvárásoknak, amelyek a 19. század közepén kialakuló modern tömegmédiumok szerkezetét meghatározzák. A Pesti Napló 1850-ben azzal az akkoriban korszerünek számító lapstruktúrával indult útjára, amely a nyomtatott médiumoknak ebben a korszakában alkalmas lehetett a kifejlett társadalmi nyilvánosság megteremtésére és megszólítására. ${ }^{3}$ A politikai és gazdasági hírszolgáltatás mellett jelentékeny, a lap teljes terjedelmének negyedét kitevő reklámfelület a szórakoztató programsáv megjelenésének hátterét is biztosította, a korábban „klasszikusnak” tekinthető, ismeretterjesztő tárca mellett a legfontosabb innováció a folytatásos regényközlés, a tárcaregények rendszeres jelenléte a napilapban. A lap tárcakínálata kifejezetten gazdag, az ötödik évfolyamába lépő újságból lassan elmaradnak a rövidebb terjedelmű tárcanovellák, és a sokszor hónapokon

\footnotetext{
${ }^{1}$ Gyulai utal is erre a Magyar Tudományos Akadémián 1879. május 25-én tartott emlékbeszédben: „Kemény az Angol királynőbe költözött, a hol Deák is lakott, újra regényeket írt, majd 1855-ben átvette a Pesti Napló szerkesztését, amelyre azelött is többé-kevésbé befolyással volt. A szenvedőleges ellenállás és várás politikájának senki nem volt oly kifejező képviselője, mint Deák, az államférfiú és Kemény, a hírlapíró" (Kiemelés tőlem - H. Á.) Gyulai Pál, Kemény Zsigmond = Gy. P., Emlékbeszédek I-II., Bp., FranklinTársulat, $1902^{2}$, I, 185.

² SzEGEDY-MAszÁk Mihály szerint a két hosszabb cikksorozatra a leginkább a „művelődésszociológiai” jelző illene, ami alátámaszthatja a szövegek művelődési programként való értelmezésének indokoltságát. Vö. Szegedy-Maszák Mihály, Kemény Zsigmond, Bp., Szépirodalmi, 1989, 345. Pais Dezső 1911-es cikke szintén az írások programszerüségét emeli ki, azzal a megszorítással, hogy ezek valójában a tiltás alá eső politikai program helyére lépnek be. Vö. PAIs Dezső, Báró Kemény Zsigmond és az irodalmi élet (Második közlemény), ItK, 1911/2, 176.

${ }^{3}$ Jürgen Habermas, A társadalmi nyilvánosság szerkezetváltása, ford. EndrefFy Zoltán, Bp., Gondolat, 1971, 114. (Németül: Jürgen Habermas, Strukturwandel der Öffentlichkeit: Untersuchungen zu einer Kategorie der bürgerlichen Gesellschaft, Frankfurt am Main, Suhrkamp, 19954, 120-121.)
} 
keresztül folyó regényközlések epizódjai váltakoznak a tudományos ismeretterjesztő sorozatokkal.

A tárcaregény európai „klasszikusai” mellett folyamatos az originális, magyar regények közlése. 1855 januárjától novemberéig Paul Féval „bestsellere”, A nők paradicsoma jelenik meg Greguss Ágost fordításában, ${ }^{4}$ tavasszal-koranyáron, ezzel párhuzamosan indul el Jósika Miklós regénye, $A$ rom titkai, ${ }^{5}$ ami a korábbi regényközlési gyakorlathoz képest újítást jelent. ${ }^{6} \mathrm{~A}$ párhuzamos közlés a tárcarovat és a regény súlyának egyidejü növekedését jelzi, még akkor is, ha európai összevetésben ez (tehát kettő vagy több regény egyidejü tárcaközlése) inkább a kisebb politikai súllyal bíró, olcsóbb újságokra volt jellemző.7 Sőt: a kontinentális Európában a jelentékeny befolyással bíró, minőségi „nagy lapok" ekkoriban a rövidebb prózai müfajok tárcaközlését részesítik előnyben, a regények szerializációja inkább a népszerübb napilapokra jellemzö. ${ }^{8}$ Norbert Bachleitner az 1855ös év bécsi és pesti lapkínálatát összehasonlító elemzésében arra is rámutatott azonban, hogy miközben mind az osztrák, mind a magyar sajtópiacon a 19. század második felében - vagyis a nyugat-európaihoz képest némi késéssel - épül csak ki a tömegsajtó rendszere, ${ }^{9}$ a pesti lapok kínálata a bécsihez képest jóval kevéssé tagolt. A pesti sajtókínálatból a népszerủ és ezért értelemszerüen olcsóbb lapok hiányoznak. ${ }^{10}$ Bachleitner okfejtése alapján ezzel is magyarázható, hogy az egyetlen ellenzéki sajtóorgánumként számba vehető Pesti Napló regényközlési gyakorlatának több olyan eleme is megfigyelhetö, amely a lényegesen tagoltabb sajtópiacokon a populáris lapokra jellemző inkább. A véleményformáló, drága, magas minőséget képviselő bécsi politikai napilapok irodalmi kínálatát az autonóm iro-

\footnotetext{
${ }^{4}$ Paul FÉval, A nők paradicsoma, ford. Gerő [Greguss Ágost], Pesti Napló, 1855. január 9. - 1855. november 7., 151 epizód.

${ }^{5}$ Eszther szerzője [JósıKa Miklós], A rom titkai, Pesti Napló, 1855. április 1. - 1855. július 12., 46 epizód. ${ }^{6} \mathrm{Az}$ 1855-ös év katalógusát lásd HansáGi Ágnes, Tárca - regény - nyilvánosság: Jókai Mór és a magyar tárcaregény kezdetei, Bp., Ráció, 2014, 388-389.

${ }^{7}$ Klaus-Peter Walter két év, az 1868-as és az 1884-es év teljes francia tárcaregény-inventáriumának statisztikai adatait értékelve a következőképpen fogalmazza meg ezt a törvényszerüséget: „Minél olcsóbb, és ezáltal minél erőteljesebben a kommersz, eladható szórakoztatásra orientált egy napilap, annál több és annál hosszabb tárcaregényt vesz fel tartalomkínálatába, annál inkább tekint el rövidebb elbeszélések közreadásától azért, hogy a regény számára minél több helyet felszabadítson." Hans-Jörg NeuschäFER, Dorothee Fritz-El Ahmad, Klaus-Peter Walter, Der französische Feuilletonroman: Die Entstehung der Serienliteratur im Medium der Tageszeitung, Darmstadt, Wissenschaftliche Buchgesellschaft, 1986, 24-26. A mindennapos, megszakítások nélküli és szimultán regényközlés gyakorlata 1863-tól válik általánossá az ebben az évtizedben elterjedő olcsó, bárki számára hozzáférhető, számonkénti eladásra építő francia napilapokban, amelyekben a politika helyét a szenzáció, a színes hírek, és természetesen a 150-200 epizódra is elnyúló fikciós próza vette át. Vö. Uo., 49 skk., különösen: 58.

${ }^{8}$ Vö. Norbert BACHLeITner, Politik und Unterhaltung: Literatur in der Wiener und Pester Tagespresse des Jahres $1855=$ Zur Medialisierung gesellschaftlicher Kommunikation in Österreich und Ungarn: Studien zur Presse im 18. und 19. Jahrhundert, hg. Norbert Bachleitner, Andrea Seidler, Wien, LIT Verlag, 2007, 138.

${ }^{9}$ Uo., 133.

${ }^{10}$ Uo., 138.
} 
dalomhoz tartozó, rövidebb prózai műfajok dominálják, és - mint arra Bachleitner elemzése rávilágít - idegen nyelvü irodalmi müvek fordításban kizárólag ezekben a sajtóorgánumokban kapnak helyet. Az olcsóbb és nagyobb példányszámú, nem az elitnek készülő lapokat ezzel szemben a rövidpróza és a „klasszikus” tárcatartalmak, az ismeretterjeszto” írások hiánya jellemzi: ezek helyét itt az anyanyelvi, „lokális” kötöttségü és érdekeltségü, nagy terjedelmü fikciós próza, a regény veszi át. ${ }^{11} \mathrm{Az}$ irodalom mediális feltételrendszere szempontjából azonban ezek a különbségek nem befolyásolják azt a körülményt, hogy „a tárgyalt korszakban az irodalom már nem elsődlegesen a könyv, hanem egyre inkább a folyóiratok és újságok számára íródik". ${ }^{12}$

A Pesti Napló tárcarovatának első öt évében nem találunk példát a párhuzamos regényközlésre: az új széria mindig a korábbi lezárulása után indul útjára. 1855 áprilisától a Féval- és a Jósika-regény szimultán közlése nem azon a módon valósul meg, hogy az egyes lapszámokban a két regény epizódjai váltakozva követik egymást; egy lapszámban a tárcarovat mindkét regényből hoz új epizódot. (Biztos kivételt csupán a keddi napok jelentenek, ilyenkor a vezércikk általában kiszorítja a tárcát.) A júliusi, aszályos hírszezon első két hetét egy harmadik regény, $A$ régi jó táblabirák ${ }^{13}$ közlésének elindításával hidalják át a szerkesztők. A régi jó táblabirák tárcaközlésének megindulásakor A nők paradicsoma pár hétre leáll: A rom titkai közlésének üteme azonban felgyorsul, és az utolsó epizód után a szimultán közlésben ismét a francia regény fordításának epizódjai szerepelnek az originális magyar regény mellett. A párhuzamos regényközlésben tehát továbbra is két regény, egy magyar és egy fordítás vesz részt, a szimultán közlés azonban azt vonja maga után, hogy a rövidpróza, a tárcanovella, még az egyepizódos is, teljesen eltünnek a rovatból. Miközben a szépirodalom, illetve az elbeszélő fikció területén a regény ekkor teljes győzelmet arat, az európai minőségi, véleményformáló és ezért drága napilapokra jellemző tudományos, tudományos-ismeretterjesztő sorozatok, tárcatartalmak továbbra sem tünnek el a lapból. ${ }^{14}$

A Pesti Napló önértelmezését az ötvenes évtized első felében mindazonáltal nem csupán a magyar nyelvü politikai napilapok kínálatának és magának a piacnak a szükössége határozta meg. Vagyis az arra való reflexió, hogy a Pesti Naplónak az előfizetők társadalmi és jövedelmi státuszától némiképp függetlenül a hiányzó népszerűbb, populáris(abb) sajtóregiszter bizonyos funkcióit is el kellett látnia. Erre nem utolsó sorban az előfizetői háztartásokhoz „családtagként” vagy egyéb módon, például alkalmazottként kapcsolódó és sokszor láthatatlan nő- és gyermekolvasók miatt lehetett szükség. A terjedelmes, hónapokon át futó tárcaregényközlések és a nem ritkán naptári éven átívelő tudományos munkákból készült sorozatok békés egymás mellett élése a

\footnotetext{
${ }^{11}$ Uo., 138 skk.

${ }^{12}$ Uo., 133.

${ }^{13}$ JókAi Mór, A régi jó táblabírák, Pesti Napló, 1855. július 2. - 1856. március 16., 87 epizód.

${ }^{14} 1856$ májusától a Szomorú napok epizódszüneteiben CsENGERY Antal Az avarok története címü történeti tanulmányát közlik folytatásokban.
} 
tárcarovatban nem annyira a politikai napilapok hálózatának fejletlenségére, hanem sokkal inkább a printmédiumok általános helyzetére volt visszavezethető. A magyar médiapiacról az évtized első felében nem csupán a népszerűbb, és ezért olcsóbb, többek számára hozzáférhető napilapok hiányoznak, hanem azok a tematikusan szakosodott hetilapok, illetve folyóiratok is, amelyek szélesebb olvasóközönséget érhetnének el. Az 1854-es év tárcakínálatát értékelő visszatekintés tanúsága szerint a Török János szerkesztette Pesti Napló a hosszú regénysorozatokkal nem kizárólag a népszerübb napilapok hiányában a populáris regiszter egy fontos feladatát szándékozott magára vállalni. A szélesebb közönség érdeklődésére számot tartó irodalomtörténeti, történelmi, néprajzi és természettudományos sorozatokkal azt az ürt is be kívánta tölteni, amelyet a hetilapok és folyóiratok hiánya okozott.

Folytonos figyelemmel kísérni a magyar irodalom legújabb mozgalmait, ezeket időről időre természetes összefüggésökben felmutatni régibb íróink alkotásaival, s magát az irodalmat önálló, komolyabb irányú, tudományos dolgozatok közlésével egyenesen és igenleg gyarapítani: ezek voltak a föcélok, melyeket a P[esti] Napló szerkesztője magának kitűzött, midőn e lapban „tudomány és irodalom” számára állandó rovatot nyitott. E rovat megalapítására ösztönzé őt: egy részről a minden emberi haladásban következetesen nyilatkozó törvényszerűség, melynél fogva a virágnak gyümölccsé kell érlelödnie, s melynél fogva irodalmunkban is, mely sokáig kiválólag a belletristika és politika terén fejtett ki nagyobb tevékenységet, most már elutasíthatatlan szükséggé vált a szigorúbban tudományos búvárlat, az ismeretek, $\mathrm{s}$ kivált a gyakorlatiak rendszeres gyüitése és terjesztése; más részről pedig ösztönzé őt erre oly magyar folyóiratbani fogyatkozásunk, mely kizárólag a tudományos irodalmat képviselné nemcsak, de egyszersmind az összes irodalom felett bíráló szemlét tartana, ismertetné - ha röviden is - az újabb irodalmi termékeket, s lehető legkimerítőbb könyvészeti jegyzék segélyével a magyar sajtó egész működését evidentiában tartaná. Hogy a P[esti] Napló, mint politikai és napi lap, ezen irodalmi föladatnak teljesen nem felelhet meg, hogy az egy még nem létező, s kizárólag könyvismertető és könyvészeti folyóiratot nem pótolhat: azt minden elfogulatlan elismerendi, a nélkül, hogy ezért a P[esti] Naplóban nyitott irodalmi rovat hasznos, sőt szükséges voltát kétségbe vonná. ${ }^{15}$

A cikk szerzője szerint azt a tényt, hogy a rovat korigényt elégít ki, nemcsak a közönség véleménye bizonyítja, hanem a tudományos közlemények területén tapasztalható élénkülés is. Az a tudatos törekvés, hogy a médiapiac beszükülésének következtében „ellátatlan” tájékoztatási, információforgalmazási feladatokat a Pesti Napló lehetőségeihez mérten minél szélesebb körben teljesítse, a legnyilvánvalóbban a könyvészet kap-

${ }^{15}$ [N. N.], Tudomány és irodalom: Visszatekintés a Pesti Napló irodalmi rovatának 1854-dikévi folyamára, Pesti Napló, 1854. december 31. (vasárnap), 2. 
csán fogalmazódik meg a cikkben. Köteles példányok hiányában a Pesti Napló célként sem tekinthet a teljes magyar könyvészet közlésére, a lényegében arculatidegen rovatról azonban azért nem mondhat le a szerkesztőség, mert „sok újabb munkát még a pesti könyvboltokban sem lehet felkutatni”. Az évértékelő írás a tárcarovat funkcióját nem annyira a fikciós próza szórakoztató „programsávjában”, mint inkább a közművelödés előmozdításában jelöli ki, amely a Pesti Napló egyik fontos célkitüzése, amint ezt az önálló rovat vizuálisan is érzékelhetővé teszi. Roppant tanulságos végigtekintenünk azokon a szerzőkön és műveken, akikre és amelyekre az írás szerzője hivatkozik. Toldy Ferenc egyetemi előadásait a magyar költészet történetéről még 1853 folyamán kezdték el folytatásokban közölni, és a közlés átnyúlt a tárgyalt, 1854-es évre; hasonlóképpen e cél megvalósítását szolgálta Greguss Ágost verstanának szeriális közlése, amiként az 1853ban Jeles íróink csarnoka címmel útjára indított sorozat is, amely havonként két-két portréval járult hozzá a közművelődés ügyéhez. ${ }^{16}$ Török János számára a történelem mellett a „népisme”, az utazások, müvészetek, nemzetgazdászat, archeológia, egészségügy, ipar, nyelvészet hasonlóképpen lényeges tematikus csomópontjai az ismeretterjesztésnek.

1855 végén az akkor már Kemény Zsigmond által jegyzett lap Eugène Sue regényét, Az ördöngös orvost azzal a szerkesztői megjegyzéssel ajánlja az olvasók figyelmébe, hogy annak cselekménye mellett „a lélektani fürkészések” és a társadalomrajz is figyelmet érdemelnek, különösen, mert a regény árnyalt képet kínál a „jelenkor nőtípusairól”. ${ }^{17}$ Hogy a szerkesztők mennyire komolyan számolnak az olvasói szokásokkal, azt nem kizárólag az induló sorozat nőknek címzett ajánlása jelzi. A Pesti Napló önértelmezését a korabeli lapok hálózatának és olvasói raszterének együttes és pontos ismerete határozza meg. Az 1855. június 14-i számban az Ungarische Post kéthasábos, nagyméretü, német nyelvü hirdetéséhez füzött szerkesztői megjegyzés is erről tanúskodik. „Miután tudjuk, hogy nagyszámú magyar lapokat olvasó tisztelt közönség még ezenfelül egy német lapot is tartani szokott, bátorkodunk ezennel az Ungarische Post címü nagy politikai lapot ajánlani, mely a mellett, hogy a híreket, melyeket a bécsi lapok hoznak, hasonló gyorsasággal közli, különösen a magyar érdekeket képviselendi.” A Pesti Napló saját médiapiaci környezetének és pozíciójának meglepően pontos értékelése ellenére sem tudja stabilizálni az előfizetések számát, és így anyagi helyzetét sem; tartósan a rentabilitási küszöb (2500) körül vagy az alatt mozognak a példányszámok. A Pesti Napló tárcarovata a lap megindulásától kezdődően, különösen az eredeti, magyar regények közreadásával, azt a gyakorlatot követte, amely a kontinentális Európában ${ }^{18}$ az olvasás - pontosabban a regényolvasás - általános időtöltéssé válását és a „tömegesedő” olva-

\footnotetext{
${ }^{16}$ Bár a legtöbb portré szerzője a rovat vezetője, Greguss Ágost, Kemény Széchenyi-portréja is ebben a sorozatban látott napvilágot.

${ }^{17}$ Eugène Sue, Az ördöngös orvos, ford. [N. N.], Pesti Napló, 1855. november 20. - 1856. március 23., 58 epizód. A rövid elemző-ismertető ajánlás az első epizód előtt szerepel a rovatban. Vö. Pesti Napló, 1855. november 20.

${ }^{18}$ És, tehetjük hozzá, Dél-Amerikában, Japánban, Ausztráliában, Oroszországban, valamint Észak-Amerikában a nem angol nyelvü közösségek esetében, vagyis végeredményben globális jelenségröl van szó.
} 
sási igények kielégítését nagyjából az első világháborúig a leghatékonyabban szolgálta. Magyarországon és Németországban a tárcaközlés 1938-ig a regénykiadás legfontosabb piaci, illetve marketingstratégiáját is jelentette egyúttal. A könyvkiadást intézményesen is összekapcsolta a tömegmédiával, ekkoriban a napilappal, hiszen csak az a regény jelenhetett meg a könyvpiacon, amely már „átesett” a tárcaközlésen, vagyis az olvasóközönség igent mondott rá.

Az Élet és irodalom cikksorozatának ötödik részében Kemény maga is értelmezi az olvasóközönség fogalmát, és analízise nagymértékben egybevág azzal a programmal, amelyet a 19. századik második felében a napilapok tárcarovatai valósítottak meg. „Nemcsak nálunk, de a világon mindenütt a nagy olvasóközönség alatt azon kört értik, hová a szépirodalom behat, s hová legalább a versek és regények olykor elérkeznek, földeríteni egy unalmas téli estét, élvezhetővé tenni egy esős és munkátlan napot." ${ }^{19}$ Vagyis: Kemény nem ítéli el a szépirodalomnak azt a funkcióját, amely mindenekelőtt az időtöltést és a szórakozást szolgálja, hiszen abból indul ki, hogy a szépirodalmon túl „[minden] más elmeterménynek keskenyebb köre van, még akkor is, ha több vásárlója akad; mert, mint tudatik, a szépirodalmi müveket szokták leggyakrabban átkölcsönzeni, s közülök egy példány néha száz kezen is fordul meg." ${ }^{\prime 20} \mathrm{~A}$ nemzeti művelödésnek szükséges és kívánatos eszköze is a szórakoztató irodalom, hiszen a szellemi emelkedéshez és a nemzeti művelődést előmozdító tudományos könyvkiadáshoz Kemény érvelése szerint az olvasáskultúrán, az olvasóközönség kialakulásán, vagyis a könnyedebb olvasmányokon keresztül vezet az út. A tudást és tudományt, a kultúrát általában megbecsülő közszellemet szerinte „azon sok száj terjesztheti, mely a legkönnyebb olvasmányok - tehát a szépirodalom - közönségeé". ${ }^{21}$

Kemény okfejtésében az olvasást értékként elismerő közszellem kialakulása olyan célként jelenik meg, amely az irodalom intézményrendszerének és nyilvánosságának

\footnotetext{
${ }^{19}$ Kemény Zsigmond, Élet és irodalom, V., Pesti Napló 1852. november 10. (szerda), 1. Lényeges lehet, hogy az Élet és irodalom részei rendre a vezércikk helyén és funkciójában szerepelnek. Az újságoldal térelosztásának szemiotikája tehát eleve azt az olvasói utasítást lépteti életbe, hogy az egyes részeket és a széria egészét is programként kell aktualizálni. 1852 és 1853 folyamán három szériában jelennek meg Élet és irodalom címmel Kemény vezércikk-sorozatai: 1853. január 8-án, a szombati szám első oldalán a második sorozat első része négy hasábon jelenik meg, szinte a teljes oldalt kitölti. A címhez (Élet és irodalom) Kemény csillaggal megjegyzést füz: „Minden cikkeim, melyek szorosan külföldi ügyekre nem vonatkoznak, ezen cím alatt fognak megjelenni. Kemény Zsigmond." Kemény a korábbi epizódokat név nélkül közölte, vagyis ezt a szériát már szerzői kézjeggyel ellenjegyezve bocsátja útjára. A hét részből álló sorozat darabjai a következő számokban jelentek meg: 1853. január 8., január 9., január 15., január 18., január 19., február 9., február 10. Ezt a középső, januári szériát sem Papp Ferenc, sem Tóth Gyula nem sorolják az Élet és irodalom szövegkorpuszához, követve a Gyulai Pál által kialakított cikluskompozíciót. Vö. PAPp Ferenc, Báró Kemény Zsigmond, Bp., MTA Kiadása, 1923, II, 188-189.; Tóтн Gyula, Utószó = KeмÉny Zsigmond, Élet és irodalom: Tanulmányok, Bp., Szépirodalmi, 441-443. A továbbiakban a Pesti Naplóban megjelent szövegekre hivatkozom.

${ }^{20} \mathrm{Uo}$.

${ }^{21} \mathrm{Uo}$.
} 
az átalakulását is megköveteli. Bár Kemény mindkét cikksorozatában következetesen könyvolvasásról beszél - mintha a vezércikkek írója számára a szépirodalom olvasása evidenciaként könyvolvasást, a könyv médiumától elválaszthatatlan tevékenységet jelentene -, mindkét ciklusában többször visszatér ahhoz a két feltételhez, amelynek teljesülése nélkül a nemzeti müvelődés programja aligha volna megvalósítható. $\mathrm{Az}$ egyik az olvasók körének a szélesítése, ${ }^{22}$ a másik pedig, ami ezzel szorosan összefügg, az irodalmi „termelés” növelése, vagyis az új címek folyamatos és bőséges biztosítása. „S virágzó literatúrának tulajdonkép csak azt lehet nevezni, melyben folytonosan annyi szépirodalmi mủ jelenik meg, hogy az új termények egy olvasáshoz szokott nőnek üres idejét egészen elfoglalhatják.” ${ }^{23}$ Kemény számára a „virágzó literatúra” mércéjét nem a kiugró teljesítmények jelentik. Friedrich Schlegel nagyhatású tanulmánya ${ }^{24}$ óta szinte a „természeti törvények” rangjára emelkedett közhellyé vált az az elképzelés, mely szerint egy nemzeti irodalom kiteljesedését az olyan „csúcsteljesítmények” megszületése jelzi, amelyek képesek bekerülni a nemzetközi vérkeringésbe, vagyis amelyek forditásban léteznek. Az irodalom (elit) esztétikai kánonjában egy korszak „jellemzo” vagy „átlagos” művészeti teljesítményeihez képest mindig inkább az „atipikus” művek sorozatai jönnek létre. Amikor Kemény leírja azt a (bátortalannak éppen nem nevezhető) mondatot, hogy valójában a forradalmat megelőzően „sem volt virágzó literatúránk,", véletlenül egy explicit performatívummal magára a beszédaktusra irányítja a figyelmet. Ezzel is nyomatékot adva annak a tézisnek, mely szerint a virágzó irodalom nem az opus magnumok létének vagy nem létének a kérdése. „Halhatatlan műveink támadtak, - t[udni] i[illik]: oly auxesissel ruházva e címet nevezetes íróink legjobb szerzeményeire, mint a franciák és a németek szokták a magokéira - ismétlem, kitűnő becsü műveink voltak; de azok mellett nem jelent meg elég mennyiségü érdekes olvasmány, mely a nagy közönséget szüntelenül foglalatoskodtatta volna."26

\footnotetext{
${ }^{22}$ Azzal a megszorítással, hogy Kemény, akinek lesújtó képe van a korabeli magyar művelődési viszonyokról, ezen távolról sem az irodalom demokratizálásának (Európában ekkor már aktuális) programját érti. Ennek indokairól a Szellemi tér III. részében beszél részletesebben: „Nekünk ezen években s körülmények közt, különösen a nővilágot és a magasabb helyzetűeket kell irodalmunkhoz hódítani; mert ha velök szakítunk, ha nekik nem tudunk hazai nyelvünkön oly könyveket adni, melyeket ne csak honfiságból vásároljanak meg, hanem kíváncsiságból és tudvágyból el is olvassanak: szóval ha verseket csupán a népnek, tudományos munkákat csak az iskoláknak írogatunk: úgy könnyen megtörténhetik, hogy mielött az új publicumot megteremtenők, markunkba szakad a dolog, s az irodalom oltáránál parlagi költőkön és kézikönyv-gyártókon kívül nem sok egyén fog tömjénezni, s betelik azok jóslata, kik meg vannak győződve, hogy ezentúl minden míveltséggel bíró vagy azt megszerezni vágyó magyar, saját literatúráját mellőzni fogja." Kemény Zsigmond, Szellemi tér, III., Pesti Napló, 1853. augusztus 28. (vasárnap), 1.

${ }^{23}$ Kemény, Élet és irodalom, V., Pesti Napló, 1852. november 10. (szerda), 1.

${ }^{24}$ Vö. Friedrich Schlegel, A görög költészet tanulmányozásáról, ford. TANDORI Dezső = August Wilhelm Schlegel, Friedrich Schlegel, Válogatott esztétikai írások, szerk. Zoltai Dénes, Bp., Gondolat, $1980,130$.

${ }^{25}$ Uo.

${ }^{26}$ Uo.
} 
Kemény számára ugyanakkor az olvasás nem az irodalom belügye: olyan társadalmi kérdés, amelynek politikai dimenzióját a vidéki nemességgel összefüggésben világítja meg. Ha az irodalom és az olvasás a politika eszközeként tünik is fel ebben az érvelésben, nagyon fontos azt hangsúlyozni, hogy Kemény nem direkt politizálásról beszél, sőt, egy azzal merőben ellentétes funkcióra irányítja az olvasó figyelmét. Kemény felismeri az irodalomnak - és nem is feltétlenül csak az esztétikailag értékes irodalomnak - azt a dinamizáló „képességét”, amelyet Ludwig K. Pfeiffer a kultúrák alapvető szükségletének nevezett, és amelyet szerinte a médiumok (vagy hagyományosan müvészetek) voltak/vannak hivatva kielégíteni. Az irodalom az egyik legfontosabb forrása ${ }^{27}$ azoknak a „megkapó, lelkesítő tapasztalatoknak”, amelyek „nélkül a szociális és a privát életformák imaginatív szempontból kiszáradnának. Az imaginárius-vitális cselekvési láncolatok elvesztésével a kultúrák majdan "cselekvőképességüket« is elvesztenék."28

Amikor Kemény azt mérlegeli, hogy a megyei közélet, a gyakorlati politizálás megszüntével a vidéki nemesség miként őrizheti meg „ítélőtehetségét," szellemi vitalitását (értsd: cselekvőképességét arra az időre, amikor erre a gyakorlati politikában ismét szüksége lesz), az irodalom pártolásában találja meg azt a „vidéki nemesség önmüvelésére még fönnmaradt eszközt”, 29 amely a „szellemi eltompulástól” bár nem egyedüliként, de megmentheti. Kemény a kis- és középbirtokos osztályt olyan társadalmi erőként írja le, amelytől „a haza jövendője nagy mértékben függ”. ${ }^{30} \mathrm{~A}$ polgáriasodáshoz elengedhetetlen önképzés azon két területe közül, amely az ötvenes évtized elején Kemény helyzetértékelésének az értelmében még nyitva áll ez elött a társadalmi csoport elött, az olvasás, az „irodalom hü pártolása” 31 ebben az okfejtésben „csupán” a második helyre kerül. Elsőként ugyanis a mezőgazdaságot említi: azt a gazdasági területet, amely a vidéki magyar nemesség számára kézenfekvő és körülményeiből eredően adott cselekvési tér. A mezőgazdaság azonban csak abban az esetben válhat a nemesség polgárosodásának (és tegyük hozzá, polgári öntudatának identitásteremtő) alapjává, amennyiben „tudományosan”, „intenzíven”, „okos számítással”, vagyis professzióként művelik. A foglalkozásszerűen végzett munka, különösen az olyan gazdasági tevékenység, amely a piaci szereplőket

\footnotetext{
${ }^{27}$ A könyv mint tárgy tulajdonságainak köszönhetően hordozható, tömeges, viszonylag könnyen férhető hozzá, emiatt a művészetek és általában a kultúra médiumai között sokáig nincsen valós versenytársa. ${ }^{28}$ Ludwig K. Pfeiffer, A mediális és az imaginárius: Egy kultúrantropológiai médiaelmélet dimenziói, ford. Kerekes Amália, Bp., Magyar Műhely - Ráció, 2005, 21.

${ }^{29}$ Kemény, Élet és irodalom, IX., 1852. december 2. (csütörtök), 1.

${ }^{30} U$.

${ }^{31}$ „A közép és kisebb birtokú osztálynak, ha jelentékenységét, melytől a haza jövendője nagy mértékben függ, nem akarja kockáztatni, s ha a míveltség- és polgáriasodásban magát szándékosan túlszárnyaltatni nem törekszik, folytonos önképzésre még két hatalmas eszköz van kezei között. [...] A egyik: hogy a mezőgazdaságot, melyet eddig többnyire csak szutyongatott, ezentúl intensive, lehetőleg tudományosan, s okos számítással üzze. [...] Áttérek a második eszközre, mely vidéki nemességünk önmívelésére nézve még fönmaradt. S mi ez? Az irodalom hő pártolása. Az olvasás komoly célból és időtöltésre. Régen egész vidékeket beutazhattunk, anélkül, hogy újabb könyvre találnánk, s a tekintetes úr, veleszületett büszkeséggel beszélt az »ironcokról«" Uo.
} 
folyamatos versenyre és ettől nem függetlenül „fejlődésre” készteti, mintegy kikényszeríti az „önművelést”. Az olvasás Kemény argumentációjában így válik a (civil) társadalom megerősödésének legfontosabb eszközévé. Egyrészt az információszerzés és az információforgalmazás technológiájaként közvetlenül feltétele a gazdasági fejlődésnek, másrészt, szabadidős tevékenységként, az egyént, az egyénekből kiépülő közösséget és így az általuk hordozott kultúrát is életben tartó, dinamizáló, szubverzív élményekhez segíti hozzá. ${ }^{32}$

Nem sokkal később, a Szellemi tér cikksorozatában ezt a gondolatot füzi tovább, de ezúttal már nemcsak a vidéki kisnemességre, hanem az olvasóközönség egészére, a női olvasókra is kiterjesztve érvényét. Amikor Kemény amellett érvel, hogy a legfontosabb cél („A magyarnyelvű olvasóközönséget, magyar könyvek olvasásához szoktatni”"33) nem érhető el pusztán azáltal, hogy a magyar nyelvü könyveket egyfajta hazafias tettként vagy szolgálatként megvásárolják, éppen az irodalom révén hozzáférhető felrázó, lelkesítő tapasztalatoknak a fontosságát hangsúlyozza. Világos különbséget tesz a vásárló és az olvasó között: míg ez előbbi nélkül nem alakulhat ki az irodalmi piac, az utóbbi nélkül a kultúra veszíti el cselekvőképességét, vitalitását. Kemény ezért is emeli ki, és helyezi a harmadik cikk zárlatába az egyik legfontosabb üzenetét: a magyar irodalomnak nem pártfogókra, hanem olvasókra van szüksége. ${ }^{34}$

Az olvasók számának növelése azonban nem egyszerüen azon múlik, hogy rendelkezésre áll-e megfelelő mennyiségü magyar nyelvü olvasmányanyag. Csak abban az esetben várható a magyarul olvasók számának tényleges növekedése, ha a magyar (szép)irodalom az olvasó számára ugyanolyan, de legalábbis ahhoz fogható (esztétikai vagy olvasás-) élményt garantál, mint a német, francia, angol művek olvasása. Keményt a már olvasó, de nem magyarul olvasó közönség megnyerésének lehetősége foglalkoztatja. A már olvasó, ámde idegen nyelvű műveket olvasó női publikum és a „felsőbb körök” magyar nyelvü irodalomra való „átszoktatásához” azt az általa formai értelemben legszabadabbnak (vagy kötetlenségében éppenséggel formátlannak) tartott müfajt, a regényt látja a legalkalmasabbnak, ${ }^{35}$ amely a Pesti Napló rovatszerkezetében meg-

\footnotetext{
${ }^{32} \mathrm{Vö.} U o$.

${ }^{33}$ Kemény, Szellemi tér, III., 1853. augusztus 28., 1. A vasárnapi cikk azzal a kérdéssel indul: „Mi ez idő szerint legsürgetőbb kötelessége, legszebb hivatása irodalmunknak?” Az idézett mondat erre a kérdésre válaszol, őszintén önkritikus folytatása a vasárnapi szám címoldalán, a cikk felütésében, pusztán modalitása és kritikai szelleme miatt is érdemes a figyelmünkre. Kemény ugyanis azzal szembesíti olvasóit, hogy a közmüvelődés, az olvasás napi rutinná válásnak területén jelentősen elmaradtunk attól az Európától, ahol ekkorra már nem egyszerúen az általános alfabetizáció, de az olvasás (mint információs vagy médiatechnika) mindennapi gyakorlattá vált. „Rég túlestek már rajta.” Bár Kemény számára a közművelődésnek ez az aspektusa a „polgárosodás” összefüggésében tematizálódik, azokat a negatív hatásokat, amelyeket ezzel összefüggésben leír, egyetlen szóval ma „demokráciadeficitként” nevezhetnénk meg.

${ }^{34}$ A III. rész a következő mondattal zárul: „Mert csak ekként lehet irodalmunk iránt állandó részvétet gerjeszteni és tartani fen, azon körökben, melyekben eddig inkább honfi pártfogóink, mint buzgó olvasóink vannak." Uo.

${ }^{35}$ A regény „a szépirodalom legnépszerűbb és legáltalánosabban elterjedt műfaja”. KemÉNY, Szellemi tér, VIII., Pesti Napló, 1853. szeptember 17. (szombat), 1.
} 
határozó programsávként van ekkoriban jelen. Az „olvasási vágy”, amelyről Kemény azt állítja, „erre van most a legégetőbb szükségünk”, ${ }^{36}$ egy-két jó könyv megjelenésével ugyanakkor nem elégíthető ki. Kemény ismét megerösíti azt a korábbi, az Élet és irodalom cikkeiben már megfogalmazott felismerését, hogy az irodalmi kultúrának nemcsak remekmüvekre, de elfogadható színvonalú lektürökre is szüksége van: méghozzá nagy mennyiségben. „Szükség pedig, miszerint a fóérintett munkássági teren ne csak egy két jó, de sok haszonvehető könyv jelenjék meg. Legalább annyi, a mennyi a szorgalmasan olvasó nőnek, és a komolyabb, azonban kellemes írmodorú könyvekre vágyó dilettánsnak, minden idejét, ha kell, igénybe vehesse." ${ }^{37}$

Az olvasás Kemény mindkét cikksorozatában olyan kultúrtechnikaként jelenik meg, amely messze túlmutatva az irodalom és a müvészet érdekeltségi körén, lényegében a polgárosulás egyik tétkérdése. Ha nem így volna, akkor puszta ellentmondásként értelmezhetné a kései olvasó, hogy ugyanaz a Kemény Zsigmond, aki a (művészetként értett) magyar irodalom egyik legégetőbb, mind az olvasóközönség, mind pedig az írók fejlődésének gátját jelentő problémáját a „komoly és hivatását értö” kritika hiányában látja, a puszta időtöltést kiszolgáló, szórakoztató, kellemes olvasmányok szükségessége mellett érvel. Kemény felismeri, hogy az olvasás, amely a 19. század robbanásszerüen fejlődő médiapiacán az információszerzés legfontosabb technikája, és egyúttal az irodalmi müalkotások befogadásának útja is, olyan napi rutint igénylő tevékenység, amelyet nem elegendő az alfabetizáció értelmében (egyszer) elsajátítani. Mind az irodalmi müalkotások, mind pedig a nyomtatott médiumokban forgalmazott információk csak azoknak az olvasóknak a számára válhatnak hozzáférhetővé, akik gyakorlottan olvasnak egy adott nyelven. Az olvasás napi rutinná válását, vagyis azt a folyamatot, amelynek eredményeképpen a mindennapos tevékenységek sorába belép az olvasás, és az addig nem olvasóból, az alkalmi olvasóból, vagy éppen a más nyelven olvasóból gyakorlott (magyar nyelven) olvasó válik, mindenekelőtt a könnyedebb olvasmányok, és kivált a regények segíthetik elö.

Azoknak a változásoknak az értékelésével kapcsolatosan, amelyek a Pesti Napló irodalmi és művelődési programjában Kemény 1855. júniusi „,hatalomátvétele” után bekövetkeztek, a mainstream irodalomtörténet-írás felfogása az elmúlt száz évben alig változott valamit. Ennek egyik meghatározó elemét igen pontosan foglalja össze Pais Dezső, aki a Napkeletben ismertette Papp Ferenc Kemény-monográfiájának második, Kemény szabadságharc utáni munkásságát bemutató kötetét. „Megismerjük Keményt, mint az ötvenes évek irodalmi életének vezéralakját, mint az úgynevezett mérsékelt irodalmi pártnak a fejét és irányadó szellemét. Szemlét tartunk e párt: a Csengery-Pákh-Gyu-

\footnotetext{
${ }^{36}$ Kemény, Szellemi tér, X., Pesti Napló, 1853. szeptember 27. (kedd), 1.

${ }^{37}$ Kemény, Szellemi tér, III., Pesti Napló 1853. augusztus 28. (vasárnap), 1. A Szellemi tér IV. részében szintén amellett érvel, hogy a már olvasó nők és arisztokraták akkor válhatnak magyar olvasókká, ha a magyar irodalom is képes lesz „kellemes és hasznos” olvasmányokat kínálni a számukra. Vö. KemÉNY, Szellemi tér, IV., 1853. szeptember 1. (csütörtök), 1.
} 
lai-kör fölött, amely az irodalom üzleti kihasználására és a népszerűség biztosítására tekintő megalkuvás ellenében egyre nagyobb határozottsággal és sikerrel harcol a tiszta irodalmiság elveért, a művészi ízlés kizárólagos jogosultságáért.”38

Ezt a közkeletű felfogást számos dokumentum is alátámaszthatja. Például Arany János Tompa Mihálynak 1857. április 19-én kelt levele, amelyben Arany Kemény felkérését tolmácsolja Tompának: „Hallj most egy új dolgot. Kemény, valami 3-4 héttel ez előtt nálam volt és beszéltünk arról, hogy a semmi komolysággal nem biró, és ipar gyanánt űzött szépirodalom ellen, mi, a kik az irodalom ügyét szívünkön hordjuk, mint egy protestálnánk azzal, miszerint egy zsebkönyvet alapítnánk meg - a hajdani Aurora szellemében - melybe évenkinti legjobb termékeinket adnók; kizárván abból minden barbar poesist, sőt egymás iránt is szigorúak lévén a bírálatban. Első törvény lenne, hogy minden tag köteles munkáját a többi tagok kritikájának alávetni, mielőtt az elfogadtatnék." ${ }^{39}$ Konszenzuális az a vélemény, mely szerint Kemény a Pesti Napló átvételekor annak irodalmi anyagára is nagy gondot fordított. ${ }^{40}$ Bár közismertek ezzel ellentétes álláspontok, mint például Vajda Jánosé vagy a Jókai Pesti Naplóból való kiüzetését gunyorosan tárgyaló Mikszáth Kálmáné, ezeket amolyan bejelentett különvéleményként szokás számon tartani, amelyeket sokkal inkább az egyéni indulatok és érzelmek, semmint a tények alakítottak. ${ }^{41}$ Kemény a közmegegyezés szerint

\footnotetext{
${ }^{38}$ PAIs Dezső, A Kemény Zsigmond-irodalom újabb gyarapodása, Napkelet, 1924/5, 462.

${ }^{39}$ Arany János - Tompa Mihálynak, 1857. április 19. (899.) = Arany János levelezése (1857-1861), s. a. r. Korompay H. János, Bp., Universitas, 2004, 50.

${ }^{40}$ Vö. Pais Dezső, B. Kemény Zsigmond és az irodalmi élet, i. m., 185.; Martinkó András, Báró Kemény Zsigmond pályafordulata, Pécs, Kultúra, 1937, 25. „Különösen nagy gondot fordított a szerkesztőség a tárcára. Itt jelentek meg Csengery Antalnak formás tanulmányai a történetírásról s a történetírókról, Erdélyi Jánosnak bölcsészeti szempontú kritikai dolgozatai s Szalay Lászlónak kisebb történelmi értekezései. Itt rajzolta meg Gyulai Pál 1855-ben irodalmi eszményeit éles és szellemes polémiáiban; itt vette szemügyre 1856 elejétől kezdve Greguss Ágost a Nemzeti Színház s a magyar irodalom életét gondos bírálatainak hosszú sorában. Az ízlés nemesítését szolgálta a tárcában Vörösmartynak, Aranynak, Tompának, Tóth Kálmánnak s Szász Károlynak egy-egy költeménye s Jókainak több regénye." PApp Ferenc, Báró Kemény..., i. m., II, 250-251.

${ }^{41}$ Vajda János levele Kemény Zsigmondnak: „A »P. Napló« szerkesztője b. Kemény Zsigmond úrnak”, Pest, 1867. december 18.: „Én már akkor fölismertem azon ligát és törekvéseit, melynek élén báró úr s még néhányan állottak azok közül, kiknek a nemzeti küzdelem alatt és utáni magatartásuk miatt nagy mérvben szervezett szoros szövetségre volt szükségök a végböl, hogy maguknak az ellenök ingerelt közvéleményben ujolag érvényt, hatást szerezhessenek. Elöéreztem, hogy ha önök szövetsége tulsúlyra emelkedik, annak roppant káros hatása lesz irodalmunkra és egész közéletünkre! Önök ellen küzdeni - keresztényi és hazafiui kötelességnek ismertem minden időben." KeméNy Zsigmond levelezése, s. a. r. PInTÉr Borbála, Bp., Balassi - ELTE, 2007, 408-409; Mıкszáth Kálmán, Jókai Mór élete és kora (1905-1906), Bp., Magyar Helikon, 1967, 223-224. (A 14., A pitymallat című fejezet a következőképpen indul: „Kemény maga is regényíró lévén s éppen az ellenkező csapáson, nem tartozott a Jókai bámulói közé, sőt léha dolognak tartotta a mesemondást, mely az olvasót, kit Kemény gyakorlati célokra és nagy feladatokra akart fölrázni, egy álomvilágban megbűvölve tartja, s teljesen szabad kezet hagyott a lap hasábjain Salamon Ferencnek és Gyulai Pálnak, s azok egypár cikkben éles kritikát eresztettek meg Jókai regényei ellen, mitse törődve azzal, hogy éppen e regények képezik a Pesti Napló vonzerejét. Ma ilyesmi lehetetlen volna üzleti
} 
nemcsak a Pesti Napló politikáját, de irodalmi irányultságát is döntően meghatározta, müködésének első fél évtizedében a lap tárcarovata határozottan magasabb színvonalon müködött, mint annak elötte; munkatársi gárdája a legjobb írókból kerül ki, a tudománynépszerüsítő, kritikai és ismeretterjesztő cikkek terén komolyan érzékelhető színvonal-emelkedés tapasztalható. ${ }^{42}$

A fenti, hevenyészett áttekintés is alkalmas azonban arra, hogy rávilágítson: Kemény szerkesztői életművének a megítélésében az értelmezők mindenekelőtt a regényíró-esztéta Kemény Zsigmond „tiszta irodalom” iránti elkötelezettségének a premisszájából indultak ki. Ez pedig alkalmasint elfedi azt a differenciát, amelyet az Élet és irodalom, valamint a Szellemi tér müvelődési programjában kidolgozott, és amely az olvasást mint kultúrtechnikát egyszerre rendeli hozzá a nyomtatott médiumok és kialakuló tömegmédiumok világában az információszerzés gazdasági és politikai, valamint a kultúra és a művészet esztétikai rendszeréhez. Az olvasás a kultúra egészét meghatározó tevékenység: az irodalom populáris regiszterének a keményi koncepcióban elsődlegesen nem az irodalomhoz mint müvészethez, hanem az olvasási rutin megszerzéséhez van köze. A szórakoztató irodalom vagy populáris regiszter szövegei (elsősorban regényszövegei) gyakorlati célú, használati szövegek, amelyekre a nemzeti művelődésnek éppen azért van szüksége, hogy kialakuljon a gyakorlott olvasók rétege. A publicista, programalkotó Kemény az ötvenes évtized elején tehát nem egyszerűen belátja és elfogadja ennek a használati célú fikciós szövegkorpusznak a létjogosultságát. A két, egymást követő sorozat írásai azt hangsúlyozzák, hogy a korabeli mediális körülmények között ez a szövegkorpusz alkotja az egyetlen, járható és Európa más országaiban már sikeresen bejáratott utat a polgárosodáshoz, a kifejlett társadalmi nyilvánosság kialakulásához.

Kemény szerkesztői müködésének legárnyaltabb és talán legizgalmasabb értékelése Gyulai Pál akadémiai emlékbeszédében olvasható. A kötelező méltatás helyett Gyulai mind az ember, mind az író, mind pedig a szerkesztő életművének a számbavételénél a kritikai attitüdöt és mai szemmel nézve talán a sokszor nyersnek ható szókimondást választotta. Gyulai emlékbeszédében végső soron nem kevesebbet állít, mint hogy Kemény éppen azért volt képes a Pesti Naplót a kiegyezés előkészítésében ennyire hatékonyan pártja szolgálatába állítani, mert sem megszólalásmódjában, sem szerkesztői metódusában nem követte a lapszerkesztés szabályait. Talán úgy is összefoglalhatjuk Gyulai érvelését, hogy hatása nem kis részben arra a kiszámíthatatlanságra volt vissza-

\footnotetext{
szempontból. Ez csak e naiv korban járta, mikor a pénz még nem volt isten és a szerkesztők nem voltak kereskedők." Uo., 223.)

${ }^{42}$ Vö. PAIs, B. Kemény Zsigmond..., i. m., 184-186. Lényegében ugyanezt képviseli az akadémiai sajtótörténet is: „A Pesti Napló tárcarovatának szépirodalmi anyaga is határozott koncepcióba illeszkedett 1855-től kezdve, s ebben csak a csiszolatlanabb ízlésủ Pompéry János szerkesztői időszaka jelentett kis kitérőt, amikor például folytatásokban megjelenhetett Vas Gereben A nemzet napszámosai című műve. Egyébként már az első Kemény szerkesztette számban helyet kapott Arany János egyik verse, ezt majd több más is követte, aztán Vörösmarty, Tompa, Szász Károly költeményei." A magyar sajtó története II/1. (1848-1867), szerk. Kosáry Domokos, Németh G. Béla, Bp., Akadémiai, 1985, 384.
} 
vezethető, amely az ekkorra már professzionális szerkesztői diskurzusokon kívül állásából fakadt: nem a szakmai elvárhatóság szerint cselekedett.

Keményt mint szerkesztőt és hírlapírót gyakran gáncsolták némely pártfelei is, a kik különben tisztelöi voltak. Nem tartották elég gondosnak és élénknek szerkesztését, s örömest gúnyolták apró botlásait. Bizonyára Kemény egy harmadrendü szerkesztőtől is sokat tanulhatott volna, hogyan kell újabb meg újabb hírekkel s érdekesnél érdekesebb hozzávetésekkel szolgálni a közönségnek, habár azok félig sem alapszanak a valóságon; hogyan kell mindennap oly vezércikkeket írni, melyek nagyon hatásosak ugyan, de nincsenek összhangban azzal az iránnyal, melynek a lap képviselöje akar lenni; hogyan kell változni, átalakulni a képzelt vagy balúl fölfogott közvélemény áramlatai között, folyvást hangoztatva a következetességet. Mindez hiányzott Keményben, de voltak oly tulajdonai, melyek a legritkábbak közé tartoznak. Lapjának határozott színezete volt, nem szeszélyből, hiúságból, bosszúból vagy érdekből, hanem meggyőződésből, s mindig tudta, hogy mit, hogyan és mikor kell írni. Nem magának akart képviselője lenni, hanem egy pártnak, s a közönség érezte, hogy szava több, mint egy hírlapíró nyilatkozata. Nem volt magyar lap, a mely oly hü tükre lett volna egy nagy párt törekvéseinek s oly nemes kifejezése érzületének és méltóságának, mint Kemény Pesti Naplója. Kemény egyet-mást elhanyagolt, de a válságos pillanatokban mindig résen állott, $\mathrm{s}$ a legfontosabb kérdéseket tárgyalta. Taktikája és fejtegetései a közeledés, a kiegyezés fejleményeit folyvást érlelték egész a siker végstádiumáig, midőn még egyszer Kossuth híres levele ellen szállott síkra, hogy aztán nemsokára örökre elnémuljon. ${ }^{43}$

Gyulai leírása három sarkalatos állításra épül. 1. Kemény nem volt és nem vált profeszszionális lapszerkesztővé. 2. A vezércikkíró Kemény nem követi az újságírás korabeli szabályait, megszólalásai nem egy újságíró, hanem egy politikus jó időben és jó taktikai érzékkel a nyilvánosságot befolyásoló nyilatkozatai. 3. A Pesti Naplót egy párt képviseletében, egy párt lapjaként müködteti. Az emlékbeszéd a Pesti Napló történetében a Kemény-korszakot azért ítéli kivételesen sikeresnek, mert szemben a magyar politikai sajtó más orgánumaival, a lap közvetlenül is hozzájárult a kiegyezés létrejöttéhez. Vagyis: Gyulai arra mutatott rá, hogy a Pesti Napló kommunikációjának Kemény alatt nem a kifejlett nyilvánosság volt a célközönsége. Azokat a politikában aktív és cselekvő férfiakat, illetve (mai kifejezéssel élve) véleményvezéreket, valamint lobbistákat tudta megszólítani, akik nem csak alanyai, de akik az irányulás értelmében tárgyai is a közvéleménynek.

1855 júniusától a kiegyezésig annak ellenére Kemény határozta meg a lap irányvonalát és stratégiáját, hogy két alkalommal is átadta a lap szerkesztését másnak (1856 decemberétől 1857 decemberéig Pompéry Jánosnak, és 1858 júliusától 1860 februárjáig

\footnotetext{
${ }^{43}$ Gyulai, Kemény Zsigmond, i. m., 187-188.
} 
Királyi Pálnak). 1857 végére ugyan történeti mélypontra esett vissza az előfizetők száma, 1858-tól kezdődően azonban a lap helyzete stabilizálódott, 1860-ra nyereségessé vált, 1865-ben 6000-re tudta emelni előfizetőinek számát. ${ }^{44} \mathrm{Ez}$ a folyamat azonban úgy ment végbe, hogy a Pesti Naplóból eltünt nemcsak a (példányszámok emelését és az előfizetések biztosítását garantáló) tárcaregény, hanem gyakorlatilag a tárcarovat is, a maga kulturális hírtartalmával egyetemben. ${ }^{45} \mathrm{Az}$ ezzel kapcsolatos közkeletü irodalomés sajtótörténeti magyarázat lényegében egybevágó. Ezúttal Martinkó Andrást idézve: „az elnyomatás ideiglenes jellege érezhetővé válik”, ami a szabadabb politizálás mellett azt is lehetővé teszi, hogy az újság par excellence újság legyen. Ennek következtében a Pesti Napló is mindinkább „csak” politikai napilap lesz, a szépirodalom pedig, az önálló fórumok megnyílásával, megtalálja a maga önálló médiumait. ${ }^{46} \mathrm{Az}$ akadémiai sajtótörténetben Buzinkay Géza hasonlóképpen „az irodalmi és közművelődési lapok gyarapodásával” magyarázza, hogy az irodalom és a kritika terén „kisebb feladat hárult a politikai napilapokra." ${ }^{37}$ Aligha vonható kétségbe, hogy a politikai napilapok ,testidegen", ezért a hírek világába betolakodó ${ }^{48}$ tárcaanyaga - különösen a hírtől legtávolabb álló regény - elsődlegesen a terjedelem, vagyis a rendelkezésre álló felület tekintetében mindig a politikai hírek mennyiségének a függvénye: a hírek csinálóinak és a lapszerkesztőknek a nézőpontjából amolyan töltelékanyag. A 19. század ötvenes éveitől azonban a tárcaregény, illetve a tárcanovella a politikai napilapok „kötelező" részévé vált. Az Élet és irodalom, valamint a Szellemi tér irodalmi-közművelődési programját végigolvasva már csak azért sem igazán kielégítőek ezek a magyarázatok - még ha a tárcaregény és általában a rovat eltünése, valamint a két cikksorozat megjelenése között el is telt néhány év -, mert Kemény koncepciójában kulcsszerepet kapott az olvasás, és annak belátása, hogy az olvasás napi rutinná válását mindenekelőtt a szélesebb közönséget is megszólító, szórakoztató olvasmányokon keresztül lehetséges elérni.

A kifejlett társadalmi nyilvánosság létrejöttét Jürgen Habermas a tulajdonosok gazdasági és politikai (vagyis maszkulin), valamint a nők, munkabérből élők és gyermekek (dominánsan feminin) irodalmi nyilvánosságának összeolvadására vezette vissza. Peter

\footnotetext{
${ }^{44}$ A magyar sajtó története..., i. m., 374 skk.

${ }^{45}$ 1862-ben nagyon látványos a rovat visszaszorulása, annak ellenére, hogy Jókai egy regény erejéig még visszatér $A z$ új földesúrral. Jókai regényén kívül Thaly Kálmán egy mindösszesen négyepizódos novellája az egyetlen szépirodalmi anyag 1865-ig, amikor egy szintén négyepizódos Lermontov-novella és Degré regénye, A számüzött leánya (január és április között 32 epizóddal) töri meg a „moratóriumot”, mígnem 1866-ban a rovat teljesen felszámolódik. A Magyar Tudományos Akadémia hírei, valamint a Nemzeti Színház heti szemléje a belpolitikai hírek közé kerül. Ez a helyzet csak a kiegyezés után, 1868-ban változik meg, de a rovat visszavezetése hosszú időt vesz igénybe.

${ }^{46}$ Vö. MARTinkó, i. m., 25-26.

${ }^{47}$ A magyar sajtó története..., i. m., 569.

${ }^{48}$ Bachleitner meghatározása szerint a tárcaregény „betolakodő” („Eindringling”) a hírek világában. Vö. Norbert BACHLEITNER, „Littérature industrielle”: Bericht über Untersuchungen zum deutschen und französischen Feuilletonroman im 19. Jahrhundert, Internationales Archiv für Sozialgeschichte der deutschen Literatur, 6. Sonderheft (1994), 159.
} 
Bürger elemzése igen meggyőzően olyan történetként beszéli el ezt a folyamatot, amely lényegében elválaszthatatlan az irodalmi piac kiépülésétől, ez utóbbiban pedig a politikai napilapok kötelező elemévé váló tárcaregénynek különösen fontos, katalizáló szerep jutott. ${ }^{49}$ Egyrészt, mert a gyakorlatban a tárcaregényt „,befogadó” politikai napilap ténylegesen, a maga kézbe vehető anyagiságában az a (mediális) platform, amely megteremtette e két nyilvánosság összeolvadásának a lehetőségét, egy addig ismeretlen információs és imaginatív közeget hozva létre. Másfelől, mert az így kialakuló nyilvánosság keretei egyúttal az irodalom piaci körülményeinek a feltételeit is hordozzák. A tárcaregényt tartalmazó napilap kétségtelenül az a médium, amelyet mindkét csoport okkal vesz kézbe, de amely mindkettő számára olyan tartalom hordozója is egyben, amelyet nem választott volna. Ez a „házasítás” bizonyosan az egyik, ha nem is az egyetlen föltétele a diszperz közönség létrejöttének. Innen nézve Kemény lapja akkor, amikor lemond a regényről és a tárcarovatról, nem egyszerüen a szórakoztató részt rekeszti ki az újságból, hanem olyan médiumot hoz létre, amelynek célja nem a kifejlett társadalmi nyilvánosság megszólítása.

A habermasi modell értelmében a Pesti Napló 1860 után azt a korlátozott, zárt, döntően férfiakból álló tulajdonosi nyilvánosságot akarja megszólítani, amely a politikaigazdasági érdekek mentén szerveződik. Ha a Pesti Napló rovatszerkezetének átalakulását Niklas Luhmann tömegmédia-modelljének kritériumrendszere alapján értelmezzük, ${ }^{50}$ hasonló eredményre jutunk. A szórakoztató programsáv kiiktatásával a Pesti Napló olyan sajtóorgánummá válik, amely nem teljesíti a tömegmédium minimális feltételeit, hiszen a hírek/tudósítások és a reklám programsávja mellől kiesik a harmadik pillér. Az Élet és irodalom, valamint a Szellemi tér művelődési programja, amely az olvasás általános időtöltéssé válását a „könnyebb olvasmányok” és ezen belül is a regényolvasás népszerüsítésén keresztül kulcsfontosságú célként jelölte meg, alátámaszthatja azt a benyomásunkat, hogy Kemény szerkesztői koncepciójában a tárcaregények, a szórakoztató programsáv kiiktatásának a lépését nem elsősorban a „tiszta irodalom” nevében, a szélesebb közönséget is megszólítani képes szórakoztató regény ellen vívott - tehát irodalmi - harc indokolhatta. Annak érdekében, hogy a Deák-párt fórumává váló Pesti Napló politikai küldetését teljesíthesse - vagyis pontosan azt, és csak azt a részét érje el a nyilvánosságnak, amelyre e cél megvalósítása érdekében feltétlenül szüksége volt -, Kemény tudatosan függesztette fel a Pesti Napló modern tömegmédiumként való működését. Ezzel a lépéssel a (szigorúan elvileg!) „mindenkihez”, de mindenképpen jóval szélesebb és színesebb publikumhoz szóló politikai napilap helyett olyan fórumot teremtett, amely alkalmas volt egy erősen korlátozott politikai nyilvánosság belső (párt)vitáinak a lefolytatására. Mindez pedig a máig közkeletü, mainstream felfogással szemben Gyulai Pál akadémiai emlékbeszédének első olvasásra talán merész következtetéseit támasztja alá.

\footnotetext{
${ }^{49}$ Vö. Peter BÜRGER, Literarischer Markt und autonomer Kunstbegriff: Zur Dichotomisierung der Literatur im 19. Jahrhundert $=$ Zur Dichotomisierung von hoher und niederer Literatur, hg. Christa BüRGER, Peter Bürger, Jochen SChulte-SASSE, Frankfurt am Main, Suhrkamp, 1982, 244 skk.

${ }^{50}$ Vö. Niklas Luhmann, A tömegmédia valósága, ford. BerénYi Gábor, Bp., Gondolat, 2008, 9-74.
} 
A kiegyezés után, 1868-tól fokozatosan indul meg a tárcarovat és tárcatartalom viszszavezetése. Ezt a folyamatot támogatja, hogy 1868. október elsején újraindul az esti kiadás, a napi kétszeri megjelenés pedig stabil, kiszámítható terjedelemnövekedést jelent. ${ }^{51} \mathrm{Az}$ esti kiadás első, 1868. október elseji számában már szerepel a tárcarovat, és ez a struktúra évekre rögzül is. A rendszeres színi kritika mellett visszakerül ide, korábbi helyére, az akadémiai hírek, és általában is, a kulturális hírszolgáltatás. Újra megjelennek a rovat ötvenes évtizedből ismert korábbi témasávjai: a könyvészet, a könyvismertetés, a legkülönbözőbb tudományterületekre kiterjedő ismeretterjesztés, a fürdőélet, a lóverseny, a visszaemlékezések, naplórészletek. 1869 augusztusában, átmeneti időre a tárca beolvad egy másik, a Különfélék rovatba. Az oktatást, vallást, kultúrát érintő információs anyag pedig ismét a hírsávban talál helyet. A tényleges fordulatra azonban nem kell sokáig várni. 1869. szeptember 19-én, a vasárnapi számban váratlanul, megújult címmel az első oldalon tér vissza a tárcarovat (»A „Pesti Naplö” tárczája.«), jóllehet az év hátralevő hónapjaiban hétköznapokon továbbra is a Különfélék ad helyet a kulturális tartalmaknak, állandó kolumnái között szerepel például a Szinház és müvészet vagy a Történészet. Az 1870-es előfizetési felhívások, az átmenetet jelentő, 1869-es év után egyértelmüvé teszik, hogy a tárcarovat visszavezetésének folyamata végleg lezárult, és a lap integrálja a tömegmédium harmadik pillérét, a szórakoztató programsávot (és ezzel a tárcaregényt, amely a modern politikai lapoknak ekkoriban elöírásos eleme).

A lap kommunikációs stratégiájának módosulásáról az első híradást az 1869. december elseji számban olvashatjuk: „Lapunk tárcája ezután, rendesen, regényt is közöl. A sort január 1-sején eredeti regénnyel kezdjük meg. Címe: »A kék vér«. Írta Degré Alajos. A regényt egyik közelebbi tárcánk fogja előlegesen ismertetni." A változást elörevetíti, hogy decemberben hetente többször is megjelenik a rovat a lapban. Dux Adolf tollából például Gyulai Pál költeményeiről közölnek ismertetést. Az 1869. december 12-i számban közzétett 1870-es elöfizetési felhívást Kemény Zsigmond jegyzi. A szerkesztői közlés azt adja hírül, hogy a hírlapbélyeg megszüntetésével megnyíló lehetőségek nyomán az esti kiadás a reggeli terjedelmének felére növekszik majd, és így a Pesti Napló a politika mellett behatóbb figyelmet szentelhet a művészetnek és az irodalomnak is: „Esti lapunk regényt is közöl, s ebbeli közleményei sorát eredeti müvel kezdi meg Degré Alajos közkedvességü tollából."

A regényt a Kemény által jegyzett előfizetési felhívás mintegy szimbolikus gesztussal visszahelyezi ama korábbi funkciójába, amelyet a tömegmédiummá vált politikai napilapokban az előfizetések meghosszabbításában és általában, a szélesebb publikumért, az olvasók megtartásáért folyó versenyben a kifejlett társadalmi nyilvánosság keletkezésétől fogva betöltött. 1870. március 15-én (ismét egy szimbolikus dátum!) az esti kiadás tárcarovatának nyitóhíre valójában már azt jelzi, hogy a lap visszailleszkedett a kortárs

\footnotetext{
${ }^{51} \mathrm{Az}$ esti kiadás kis formátumú, négy lap, három hasáb, a vonal alatti tárca az újságoldal alsó harmadát foglalja le, ám sokszor az első három oldalon keresztül, vagyis az esti kiadásban számottevő a tárca részesedése.
} 
tömegmédiumok rendszerébe: „A »Revue des deux Mondes« igazgatója, Bulat úr szíves engedélyével biztosítottuk lapunk számára George Sand »Margerout “ímű regényének közölhetését. Úgy szintén megszereztük lapunk számára Gaboriau »La cliquedoré« (sic!) könyvalakban még az eredetiben sem kiadott legújabb, két kötetes regényének lefordítási jogát. A közlést a jövő héten Gaboriau regényével kezdjük meg." Egy héttel később (március 22-én) pedig arról adnak hírt, hogy „Gaboriau Emil »La clique doreé« legújabb, s a francia közönségnél a »Petit Journal közlésében nagy érdekeltséget keltett" regényét napokon belül kezdik közölni.

Gaboriau Egy úri társaság című regényének első epizódja 1870. március 26-án, szombaton az esti kiadásban jelent meg, és az utolsó (123.) 1870. szeptember 22-én. A Pesti Naplóban ekkoriban alakul ki az a gyakorlat, amely a következő évtizedekben változatlan marad mindaddig, amíg a lap naponta kétszer jelenik meg. A tárcarovat mindkét kiadásban fontos szerepet kap, ám a reggeli és az esti szám között sajátos munkamegosztás jön létre. Az esti kiadás a magas epizódszámú, hónapokon keresztül folytatódó, fordításban megjelenő lektüröket, a színvonalas, de szórakoztató tárcaregényeket hozza. A reggeli kiadás tárcarovatában az ismeretterjesztő cikkek, kulturális tudósítások, útirajzok, karcolatok, bírálatok, vagyis a „klasszikus” tárcatartalmak mellett egyepizódos, eredeti tárcanovellák vagy rövidebb sorozatok látnak napvilágot. Olyan szépirodalmi alkotások, amelyeket inkább az elitirodalom korpuszába szokás sorolni. Miközben még folyik az esti kiadásban Gaboriau regényének közlése, a reggeli kiadásban 1870. június 29-én, szerdán, megjelenik az első epizódja annak a szeriális közlésnek, amely 1870. július 9-én, szombaton zárul le a hatodik epizóddal, és amely a lap történetében először és utoljára Kemény Zsigmond szépirodalmi művét tárja az olvasók elé folytatásokban. ${ }^{52}$ A cím - Töredékek „Anna” drámai költeményből - utal arra, hogy a hat epizódból álló sorozat nem egy teljes mü, csupán mutatvány. A közlést bevezető szerkesztői kísérőszöveg maga is reflektál arra az ellentmondásra, amely a rovat, a rovattal kapcsolatos elvárásokhoz kötődő sztereotípiák és a Kemény kitartó „irodalmi hallgatását" megtörő szöveg között feszül:

Kemény Zsigmond Anna című drámai költeményen dolgozik, melyből egyes töredékek közlését - a hosszabb terjedelmű verses mű egészében úgy sem levén hírlapi tárcába való - ezennel megkezdjük. A költemény VI. Károly császár idejében játszik, s meséje a király s Althánné közötti viszony, valamint a kor politikai mozgalmai körül forog. Az alábbi töredék megértésére csak azt kell még fölemlítenünk, hogy ezt az első felvonásban a király és tanácsosai közötti értekezlet előzi meg, mely a dynastia leányágának örökösödését tárgyazza; hogy a jelenet, melyben Althánné önérzete által sarkalva, és Csáktornyára készülve, véget akar vetni a császárral való

\footnotetext{
${ }^{52}$ Az epizódokat az első mutatványtól sorszámozzák. I.: 1870. június 29. (szerda), 1-2.; II. mutatvány: 1870. július 1. (péntek), 1-2.; III. mutatvány: 1870. július 2. (szombat), 1.; IV. mutatvány: 1870. július 5. (kedd), 1.; V. 1870. július 8. (péntek), 1-2.; VI. 1870. július 9. (szombat), 1-2.
} 
viszonyának, Bécsben játszik, és Irén (Althánné meghittje) beszédében Jenő alatt Savoyai Eugent érti; - a többit maga a költemény magyarázza meg. ${ }^{53}$

A hat epizód a drámai költemény második felvonásának első nyolc jelenetét közli. A nyolcadik jelenet a főhősnő, Anna utolsó, hatsoros „monológja”, amellyel nem csak a mutatványszéria, de az epizódok során kibontakozó konfliktus is egyfajta nyugvópontra jut. Ez teszi lehetővé, hogy a másfél hét alatt lefutó sorozat tulajdonképpen egyfajta töredékes-romantikus dramolettként is olvasható.

Annak ellenére, hogy a szerkesztöi megjegyzés a drámai költemény és az azt közreadó médium távolságát helyezte az előtérbe, kvázi az olvasó megértésére apellálva a szolgáltatott tartalom „komolysága” miatt, feltűnő, hogy az epizódhatárok itt is a szeriális közlés szabályai szerint jelölődnek ki, a cliff hanger elvét követve. Az első epizód például a II. jelenet felütésével ér véget, a komornyik bejelenti a császár érkezését, a két barátnő pedig gyors búcsút vesz egymástól. Az epizód zárómondatai mégsem a jelenet dialógusát lezáró szereplői megnyilatkozások, hanem az új jelenetet ténylegesen elindító és bevezetö mellékszöveg; esetünkben az alábbi, zárójelben szereplő szerzői utasítás: „Irén a mellékajtón távozik. Anna grófné a főbejárat felé siet. De már az ajtónál találkozik a császárral s az karon fogva visszavezeti a pamlaghoz és mellé ül. Szünet. Anna nyugtalan. Károly a teremre vizsgáló tekintetet vet." ${ }^{54}$

A szerzői instrukció ebben az esetben maga is a feszültség fokozását, és ennek egyik eszközeként a késleltetést célozza. Az első epizód tehát egy olyan „csúcsponttal” zárul le, amelyet az epizód egésze készített gondosan elő. A szerzői utasítás egyszerre jelenti be és indítja el a már elörevetített szakítási jelenetet, és ugyanakkor le is zárja az epizódot. A második epizód zárlata hasonlóképpen bizonytalanságban hagyja az olvasót. Formálisan ugyan Károly és Anna közös jelenetének a császár távozásával vége, így egybeesik az epizódhatárral, az uralkodó Annához intézett búcsúja azonban azt jelzi, hogy nem tekinti Anna döntését véglegesnek, és az olvasó ekkor már tudja, hogy Károly mit tervez riválisa ellen ${ }^{55} \mathrm{~A}$ harmadik epizód Anna és Althán párbeszéde közben szakad meg, és a szombati lapszám olvasójának keddig kell várnia arra, hogy megtudja, mit válaszol a megcsalt férj a hütlen, de vezeklést választó Anna nem mindennapi kívánságára. Anna azt

\footnotetext{
${ }^{53}$ Pesti Napló, 1870. június 29. (szerda), reggeli kiadás, 1.

${ }^{54}$ Uo., 2. Míg a tárcaközlésben a szerzői utasítások zárójelben, de azonos betűmérettel szerepelnek, addig a kötetkiadásban a két szövegréteg jól láthatóan elkülönül egymástól. A Papp-féle kötetkiadás jelentősen átalakítja az idézett szöveget, és nem elsősorban a 2. és a 3. mondat egyetlen mondatba való összevonása miatt. Az erőteljesebben a színészi játékra vonatkozó „Szünet.” megjegyzés, amely a párbeszéd megindulásának vagy elkezdésének késleltetését írja elő a játszó személyek, illetve a karaktereket pszichotechnikai eljárással „értelmező” olvasó számára, nem szerepel a szövegkiadásban. Vö. KemÉnY Zsigmond, Töredék az „Anna” címu” drámai költeményböl = Báró Kemény Zsigmond hátrahagyott munkái, s. a. r. PApp Ferenc, Bp., Franklin-Társulat, 1914, 459.

${ }^{55}$ „Óh Anna! Én bízom. Búcsúm csak ez: mehet! / Távozni engedem! Szabad, mikor akar. / Szívem üres. Nyitott kalicka, várj, míg / Az elrepült madár megérkezik. Az ég / Vezesse tőlem el, s vezesse vissza is." Pesti Napló, 1870. július 1. (péntek), 2.
} 
várja Althántól, hogy forduljon szembe a királlyal, és az bármit kérne tőle, tagadja meg: „Károly király bár mit kívánna ön, / Tagadja tőle meg: kegyét veszítse el. / Igenre nem legyen felelve szüntelen." ${ }^{\prime 6}$ Hasonló, párbeszédközi zárlattal végződik az ötödik epizód; a negyedik viszont ugyanazt a mintázatot követi, mint az első: Anna az éppen érkező Irénhez intézett szavai elindítják Anna és Irén kettősét, de az első szereplői megnyilatkozásnál a közlés lezárul, és a feleletre az olvasónak ismét várakoznia kell.

Miközben kései olvasóként a drámaiköltemény-töredék jambikus lejtése a Kemény számára is meghatározó Goethe-élményt, ebben az esetben a Faustot, vagy Katona Bánk bánját és Madách Tragédiáját idézhetik meg, a korabeli tárcarovatok melodramatikus regénykínálatából a házasságtörő, de büntudattól gyötört, és végül megtérö, vezeklő centrális nőalakok modellje is újrafelismerhető a főhős karakterében. (Hans-Jörg Neuschäfer a tárcaregény eme korszakának az egyik legfontosabb sajátságát mentalitástörténeti szempontból éppen ebben, vagyis az erős, irányító, kezdeményező, középponti nőalakok és az olyan új témák megjelenésében látja, mint a válás, házasságtörés. ${ }^{57}$ ) $\mathrm{A}$ fejedelmi csábítás motívumát ${ }^{58}$ az Anna második felvonása Katona Bánk bánjához hasonlatosan a haza megmentésére szervezett „pártütés” motívumával kapcsolja össze, de ez inkább csak kísérö motívuma a szerelmi bonyodalomnak, annak ellenére, hogy nem funkciótlan. Anna független, önálló nő, szuverén döntésekkel, aki csupán a hatodik epizód végén, vagyis akkor értesül Althán politikai szerepvállalásának jelentőségéről, amikor a féltékeny, sértett, elhagyott királytól a feleségét (tudtán kívül) visszahódító Althán már elfogadta a veszélyes küldetést. Az ötödik és hatodik epizódban (VII. jelenet) Althán barátainak (Kollonics, Okolicsányi és Szirmay) a színre lépése valójában azt a célt szolgálja, hogy Anna az ő szemükön keresztül, „másként” pillanthassa meg a férjét. Anna döntése, hogy véget vet a császárral folytatott viszonynak, a nagylelkủ és vele szemben maradéktalanul lovagias magánembernek szólt. Anna számára saját hűtlensége akkor válik a szó betű szerinti értelmében tragikus vétséggé, amikor a látogatókkal folytatott beszélgetés szembesíti őt Althán számára addig ismeretlen arcával.

Kemény lélektani affinitása a jelenet kidolgozásában látványosan mutatkozik meg. A VII. jelenet az egyetlen, amely nem két szereplő szópárbajára épül. ${ }^{59} \mathrm{~A}$ hatszereplős társalgás tétje éppen az, hogy Althán kilép a privátszféra megengedő és nagyvonalú passzivitásából, és Anna számára egyszerre láthatóvá válik az a nyilvánosságban cselekvő, ellenzéki vezéralak, akit a magánélet tereiben nem volt alkalma megismerni. A magánélet és a nyilvánosság térbeli elválasztottsága, amely a két, egymástól jól elkülönülő, lényegileg átjárhatatlan szféra szereplőinek rendszerét és belső hierarchiáit a másik ol-

\footnotetext{
${ }^{56}$ Uo., 1870. július 2. (szombat), 1.

${ }^{57}$ Vö. Der französische Feuilletonroman, i. m., 223 skk.

${ }^{58}$ A fejedelmi csábítás motívumáról a magyar romantika irodalmában vö. MARGócsy István, A király mulat: Fejedelmi csábitás a magyar romantikában = M. I., „...A férfikor nyarában...”: Tanulmányok a XIX. és XX. századi magyar irodalomról, Pozsony, Kalligram, 2013, 214-240.

${ }^{59}$ A zárójelenetben Anna és Althán dialógusába Irén Anna „segítőjeként”, ténylegesen „súgóként” lép be.
} 
dalhoz tartozók számára láthatatlanná teszi, a VII. jelenetben a látogatók érkezésével felfüggesztődik. A határátlépés tapasztalata azonban nemcsak Anna Althánról kialakított korábbi képét írja felül. Althán és a három vendég Anna-képe is megváltozik. A haza iránti cselekvő elkötelezettség azonban itt az országgyülésben ellenzéki szerepre készülő négy férfi politikai professziója (vagyis nem a Bánk bánból ismert heroikus lázadás), a motívum funkciója pedig az, hogy Anna Althán idegenségének a megtapasztalásában szembesüljön saját tragikus vétségével. Anna ugyan már ezt megelőzően megkísérli férjét a királynak való engedelmességtől eltéríteni, amikor azonban terve kudarcot vall, a királytól kapott parancsot egy Althánhoz intézett kéréssel tulajdonképpen a király ellen fordítja (azt kéri a férjétől, hozza haza Károly feleségét Spanyolországból, amit az uralkodó nem akar). A VIII. jelenet utolsó hat sorában, amellyel a közlés lezárul, Anna rövid monológja valójában annak a konstatálása, hogy miután Althánnal sikerült elhitetnie, kérése az egyik feleség közbenjárása a másik feleség érdekében, Althánon keresztül bosszút állt a királyon. ${ }^{60}$

Az Anna „recepcióját” sem nem inspirálta, sem nem provokálta ki az a nem elhanyagolható körülmény, hogy Kemény - aki a szeriális közléstől általában nem zárkózott el, hiszen az ötvenes évek első felében maga is él ennek a publikációs formának a lehetőségeivel a különféle folyóiratokban ${ }^{61}$ - a Pesti Naplóban ezt az egyetlen müvét teszi közzé folytatásokban. Méghozzá akkor, amikor sajtótörténeti léptékkel mérve is meghatározó szerkesztői korszaka végérvényesen lezárult. Bizonyosan önkényes értelmezői lépés, hiszen egyetlen dokumentum sem támasztja alá, nehéz azonban a váratlan irodalmi megjelenést a Pesti Napló éppen újrainduló tárcarovatában nem valamifajta szimbolikus gesztusként értelmeznünk. Olyan jóváhagyó gesztusként, amellyel a leköszönő Kemény, aki még nevét adja a regénytárca újraindításához és a Pesti Napló újbóli, tömegmédiumkénti definiálásához, íróként is hitelesíti a napilap irányában bekövetkezett fordulatot.

Az Annát sújtó felejtés azért sem magától értetődő, mert a töredékben ránk maradt szöveg 1914 után, amikor Papp Ferenc felveszi a hátrahagyott munkák közé, ${ }^{62}$ ha nem is centrális, de hozzáférhető darabjává válik az életmünek. Horváth János a kö-

\footnotetext{
${ }^{60}$ „Károly alázva lesz. A mely verem nekem / Volt ásva: abba ő esik be gondtalan. / S mivel büntetni vélt, mind rája fordítám. / Szeretni férjemet... e volna föladat, / Hiszen becsülhetem... S Károly alázva van...” Pesti Napló, 1870. július 9. (szombat), 2.

${ }^{61}$ Szilágyi Virgil Budapesti Viszhangjában jelent meg a Két boldog (1852. május 30. - 1852. június 20., 4 epizód); Visszaemlékezések címú novellaciklusa (1852. augusztus 22. - december 19., 13 epizód, vagyis a későbbi könyvregény, a Ködképek a kedély láthatárán fele), ugyanitt augusztus 22-étől, a Szépirodalmi Lapokban az Alhikmet, a vén törpe (1853. március 5. - március 24., 7 epizód), a Délibábban 1853 első félévében Poharazás alatt címmel beszélyfüzére, az Egy kaland a Missouri mellöl (1853. május 8.) és az Erény és illem (1853. május 22. - május 29., 2 epizód); valamint a Szerelem és hiúság (1853. július 3. - augusztus 21., 8 epizód). A Divatcsarnokban A szerelem élete (1853. május 30. - június 25., 6 epizód). Vö. PAis Dezső, Báró Kemény Zsigmond és az irodalmi élet (Első közlemény), ItK, 1911/1, 56; PAPp, Báró Kemény..., i. m., II, 146 sk., 166 skk.

${ }^{62}$ Báró Kemény Zsigmond hátrahagyott munkái, i. m., 447-499.
} 
tetről írott recenziójában üdvözli Papp kiadói döntését, ${ }^{63}$ annak ellenére is, hogy a kötethez írott elöszóban a közreadó mint a „küzdelmekben és diadalokban gazdag alkotó munka végét, a költői lángelmének utolsó fellobbanását" értékeli a drámai költeményt. ${ }^{64}$ Papp a szövegközléshez füzött megjegyzésekben a töredéket a hanyatló, egyre súlyosabb állapotba kerülő író élethelyzetének biográfiai kontextusába helyezi. A Pesti Napló szerkesztői közlésére alapozva - amely az első epizód megjelenésekor került a szöveg elé, részben azzal a céllal, hogy megvilágítsa a II. felvonás cselekményének előzményeit és történeti kontextusát - Papp Ferenc azt feltételezi, hogy a dráma első felvonása már készen van 1870-ben, a mutatvány megjelenésének idején. A teljes mü „nagy terjedelmére" tett utalásban ennek megerősítését látja, és mindebből arra következtet, hogy Keményt egészségi állapotának rohamos romlása akadályozta meg a drámai költemény befejezésében. A befejezetlen mü kéziratát elveszettnek tekinti. ${ }^{65}$ Papp már itt megfogalmazza azt a benyomását, hogy Kemény drámai költeménye a regény és dráma „különös vegyüléke”. ${ }^{66}$ A jellemzés finomságaiban, a karakterek megformálásban még felismerni véli a régi alkotóerő nyomait, de a drámai technika és a verses, kötött forma szerinte inkább akadályozzák Keményt, mint segítik a téma kibontásában.

A szövegközlés alapelveit Papp a kötet végén foglalja össze, felsorolva a legfontosabb változtatásokat. ${ }^{67}$ Papp Ferenc ugyan utal rá, hogy a Pesti Napló „,nem elég gonddal közölte Kemény drámai költeményét", és a hibák három nagy csoportját meg is nevezi (értelemzavaró hibák, írásjelek, verselésnek ellentmondó ékezés), a jelenetek „elszámozásának" kérdését ebben a részben nem érinti. A szövegben csillaggal jelöli meg azt a szöveghelyet, ahol az V. jelenet közben váratlanul felbukkan egy következő jelenetet „bejelento"” római szám (VIII). Nem ez az egyetlen elszámozás a tárcaközlésben: a negyedik epizód, amely az V. jelenet előző részben megkezdett folytatása, itt tévesen a III. sorszámmal indul. Talán nem véletlen, hogy a szöveg első közreadója, aki amúgy alapos filológiai munkát végez, ezeknek a hibáknak nem tulajdonít különösebb jelentőséget. A tárcaközlések olvasói hozzá voltak szokva a számozási hibákhoz: a Pesti Napló 1869-tól, a regénytárca újraindulásától sorszámozza az epizódokat, a címsort azonban nem szedik újra, így gyakran megfeledkeznek „az előzö" napi sorszám cseréjéről. ${ }^{68}$ (Ez utóbbi esetben, a 4. epizódnál is feltehetőleg erről volt szó.)

\footnotetext{
${ }^{63}$ HoRváth János, Báró Kemény Zsigmond hátrahagyott munkái, ItK, 1914/3, 371-376.

${ }^{64}$ PAPp Ferenc, B. Kemény Zsigmond irodalmi hagyatéka = Báró Kemény Zsigmond hátrahagyott munkái, i. m., 8 .

${ }^{65}$ PAPp Ferenc, Megjegyzés az Anna címü drámai költemény töredékéhez = Báró Kemény Zsigmond hátrahagyott munkái, i. m., 500.

${ }^{66}$ Uo., 501.

${ }^{67} \mathrm{Uo.}$

${ }^{68}$ 1852-ben az Élet és irodalom vezércikksorozatának első szériáját is elszámozzák: az V., 1852. november 10-i, szerdai epizód után az 1852. november 28-i, vasárnapi vezércikk tévesen VII. sorszámmal jelenik meg. A szerkesztőség december elején észleli a csúszást, így a december 5-i vasárnapi és a december 8-i szerdai vezércikk egyaránt $X$. sorszámmal jelenik meg.
} 
A dráma szövegrétegeire vetítve Papp eljárását úgy is értelmezhetjük, hogy az emendációnál kizárólag a dráma fószövegét (tehát a dialógusokat és replikákat) tekintette a drámaszöveghez tartozónak, és ebből következően a jelenetszámokba való beavatkozást nem sorolta a magyarázatra szoruló szövegkiadói döntések közé. (A jelenetek jelölése mellékszöveg.) Hasonlóképpen ezt támasztja alá, hogy az első jelenetet bevezető tartalmi összefoglalót olyan szerkesztői közleményként fogta fel, amely kizárólag a már létező első felvonás kivonataként olvasható. Ezzel azonban kizárta annak lehetőséget, hogy a három rövid bekezdésből álló szöveg második két bekezdését a drámai dialógusokhoz hozzátartozó mellékszövegként értelmezze az olvasó. A Pesti Naplóban közreadott II. felvonást összességében is a mellékszövegek feltűnő gazdagsága jellemzi. Talán erre is vezethető vissza, hogy Papp, aki láthatólag nem tekinti a mellékszövegeket a dráma dialógusokkal egyenrangú szövegrétegének, Kemény drámai költeményét olyan hibrid jelenségként értelmezi, amelyben az epikus, regényszerủ szövegelemek aláássák a dráma müfajiságát.

Az Anna értékelésében Papp álláspontja később sem változik: a kétkötetes nagymonográfia több mint ezer oldalából mindössze öt oldalt szán Kemény drámai költeményére. Papp Ferenc a tőle megszokott alapossággal veszi számba azokat a sajtóhíreket, amelyek Kemény készülő művéről tudósítanak, ám nem bővelkedik a forrásokban. A két felkutatott rövid hír egy befejezés előtt álló regényről számol be, és csupán a másodiknak van tudomása arról, hogy Kemény történeti anyaghoz fordult, III. Károly korához nyúlt vissza. Papp egy tudósításhoz füzött szerkesztői megjegyzés nyomán, miután a cikk szerzőjét Berczik Árpáddal azonosította, azt feltételezi, hogy Berczik még láthatta a készülő mü kéziratát, ${ }^{69}$ amelynek terve bizonyosan 1867 után merülhetett csak fel. Kemény könyvtárával összevetve két lehetséges történeti forrását jelöli meg a töredékben maradt münek. ${ }^{70} \mathrm{~A}$ drámai forma legnagyobb nehézségét Keményre nézve abban látja, hogy éppen arról kell lemondania, amit regényíróként a leginkább tud: a jellemzésről és a leírásról, miközben párbeszédei nehézkesek, előadásmódja egyenetlen. Az Anna Papp összegzése szerint azonban olyan kísérlet, amely „nem a romantikus költői szeszélynek, inkább a műgondnak nyilatkozása, mely a regényköltészet fejlődését szigorúbb szerkezettől s művészibb formától várta."ᄁ1

Papp forrásfeltáró lelkesedése lenyügöző, mindazonáltal elgondolkodtató, hogy meglehetősen takarékosan bánik a forráskritikával. A Pesti Napló tárcarovatának szerkesztői közleményéből, amely az első epizód előtt szerepelt, önmagában még nem következik az a tény, hogy a mutatvány megjelenésekor már készen lett volna az első felvonás. A cselekmény előzményeinek és kontextusának felvázolásához elegendő lehet akár egy a dráma szerzői utasításainak narratív szintjén, a drámai dialógusok elé ékelt magyarázat (mellékszöveg) vagy a szerző szóbeli közlése is. Másfelől: annak ellenére,

\footnotetext{
${ }^{69}$ PAPp, Báró Kemény..., i. m., II, 538 skk.

${ }^{70}$ Uo., 540.

${ }^{71}$ Uo., 543.
} 
hogy Papp Annában azoknak a hősnőknek a típusára ismer, akikre nemesisként éppen önnön múltjuk támad, és akiknek tragikai vétségét egyfajta jóvátételként a másokért hozott (pl. honleányi) áldozat sem fordíthatja vissza, a monográfus megkerüli az irodalmi párhuzamok, források, utalások kérdését. Kemény későbbi értelmezői közül szinte senki nem foglalkozott tüzetesebben a töredékkel, Martinkó András Papp nyomán „elfáradt öregségében" írt töredéknek tartja, amelyben ugyanakkor még sok minden felismerhető a korábbi regényalakok drámai megformáltságából. Anna és Irén alakjában szerinte „[a] bódító szépségü, tökéletes, de szenvedélyek s ellentétek közt hányódó női típus,” az „ártatlanság színe alatt züllött no"’72 korábban szépen kidolgozott figuráinak nyomaira ismerhetünk. Nagy Miklós - szintúgy Papp nyomán - a dráma regényszerü kompozícióját emeli ki, de irodalmi értelemben teljesen jelentéktelennek tartja, „a töredék alapján sajnos nem áltathatjuk azzal magunkat, hogy Kemény hallgatása remekmüvektől fosztotta meg irodalmunkat"."3

Bár Kemény első monográfusa, aki a töredékben maradt drámai költeményt mégiscsak a „hanyatló lángelme utolsó fellobbanásának"74 tekinti, lényegesen megengedőbb az Anna értékelésében, mint utódai, a befejezetlen és így müegészként értelemszerüen nem hozzáférhető szöveget a végül meg nem valósult, de a fennmaradt részekből mégiscsak elképzelhető imaginárius műalkotás teljességének a nézőpontjából tárgyalja. A cselekmény előzményeit, történeti kontextusát vázoló bevezető szövegből kiindulva például arra a megállapításra jut, hogy „az első felvonás nem igazi expositio, inkább becses környezetrajz, mely Anna lelki küzdelmeinek csak keretéül szolgál". ${ }^{75} \mathrm{~A}$ nem létező felvonás „elemzése” viszont éppen a dráma „drámaiatlanságának” tézisét támasztja alá, vagyis megerösíti azt a következtetését, hogy a drámai költemény valójában regényszerüsége okán illeszthető be az életműbe. Papp Ferenc a szerkesztői közlést az első felvonás helyett vagy helyén álló tartalmi kivonatként olvasta.

Amennyiben az Anna hat epizódját megkíséreljük önáló szövegként, dramolettként olvasni, a szerkesztői megjegyzés deixise nem az újságolvasó/könyvolvasó számára távollévő szövegrészre mutat, hanem kizárólag arra a hat epizódra, amelynek nyolc jelenetéből a címszereplö, Anna tragédiája bontakozik ki. Ebben az esetben funkciója mindenekelött az, hogy meghatározza a dramolett cselekményének történeti idejét, illetve a személyközi viszonyoknak azt a rendszerét, amely az olvasót hozzásegíti a „fordulat” (peripeteia) későbbi megértéséhez. Vagyis ebben az esetben az első epizód drámai dialógusát megelőző szövegnek csupán az első bekezdése olvasandó szerkesztői közlésként, a második két bekezdés pedig olyan, a drámaszöveghez tartozó mellékszöveg, amelyből az olvasó megtudja, hogy az első jelenetet közvetlenül megelőzően került

\footnotetext{
${ }^{72}$ Martinkó, i. m., 103.

${ }^{73}$ Nagy Miklós, Kemény Zsigmond, Bp., Gondolat, 1972, 220.

${ }^{74}$ PApp, Báró Kemény..., i. m., II, 543.

${ }^{75}$ Uo., 542.
} 
sor a Pragmatica Sanctio kihirdetésére. ${ }^{76} \mathrm{~A}$ dramolett cselekményének idejét így ez a bevezető szövegrész a szerzői instrukció státuszában pontosan meghatározza: 1713. április 19. Hasonlóképpen lényeges információja, hogy Károly fiatal (még nincs harminc éves), de magányos uralkodó, felesége, Erzsébet Krisztina kétévi távollét után csupán hónapok múlva tér majd haza Barcelonából.

A Pragmatica Sanctio különös történeti hátteret teremt a melodramatikus történethez, és feltételezhető, hogy a kiegyezést előkészítő Pesti Napló korabeli olvasója számára, aki néhány évvel korábban ugyanitt olvashatta Deák nevezetes 1865. április 16-i, „húsvéti” cikkét, alkalmas szignál lehetett a drámai költemény iránti figyelem felkeltésére. Salamon Ferenc A magyar királyi szék betöltése és a pragmatica sanctio története címü könyve előszavában éppen abból kiindulva határozza meg saját beszédpozícióját, hogy a magyar jogelmélet és jogtudomány a korábbi évtizedekben kellően tisztázta a Pragmatica Sanctio jelentőségét. A gyakorlati politika aktuális kérdéseire válaszoló közjogi értelmezések csúcsát Salamon Deák munkáiban látja, amelyeket a magyar politikatörténet „korszakot alkotó eseményeiként” jellemez. ${ }^{77}$ Salamon abból az előfeltételezésből indul ki, hogy az olvasók Deák írásainak köszönhetően alaposan ismerik a Pragmatica Sanctio történeti és teoretikus kontextusát, az ezzel kapcsolatos kérdések megítélését pedig egyfajta közmegegyezés övezi. ${ }^{78}$ A Pesti Napló hat epizódjának elolvasása azonban azokat az olvasói elvárásokat, amelyek a drámai költemény müfaji meghatározottságai, illetve a magyar történelemre az első közlés jelenében közvetlenül is és döntő befolyást gyakorló történelmi esemény nyomán kialakulhattak, bizonyosan nem szolgálta ki. A történelem csupán kulissza a dramolett drámai dialógusainak a hátterében: az előtérben az érzelmi folyamatok állnak, amelyek „elszenvedőik” akarata ellenére válnak történelmet alakító tényezőkké.

A dramolett cselekményében magának a Pragmatica Sanctiónak igen különös „szerepet" szán a szerző. A VII. jelenetben (amely a sorozat utolsó epizódjában volt olvasható) Althán és Anna szópárbajába beavatkozik az okos barátnő, Irén, hogy megmentse Annát a lelepleződéstől. Anna, miután értesül arról, hogy Althán nem mondott nemet a királyi megbízatásra, vagyis nem tett eleget első kérésének, egy másodikkal áll elő: „Károly király nejét sietve hozza el." ${ }^{79}$ Az érvek és ellenérvek egyre gyorsuló spiráljában

\footnotetext{
${ }^{76}$ Vö. az 53. jegyzetszám alatt a föszövegben idézett szöveg.

${ }^{77}$ Salamon Ferenc, A magyar királyi szék betöltése és a pragmatica sanctio története, Pest, Ráth Mór, 1866, VI.

${ }^{78}$ „Deák Ferenc 1861-iki és 1866-iki föliratai, 1861. június 4-iki nevezetes beszéde, s ezenkívül a »Budapesti Szemle« új (1865-iki) folyamának első füzetében megjelent polemikus értekezése, (melyet azután önállóan is kiadott) oly világos, igaz és hathatós, s annyira ismert kifejtései közjogunk legfontosabb kérdéseinek s így az e könyvben tárgyaltaknak is, hogy én, mint a kinek nem szakfoglalkozásom a jogtudomány, már csak annál fogva sem akarhattam erről az oldalról valami újat, valami eltéröt mondani." Uo., VI. (kiemelés tőlem)

${ }^{79}$ Pesti Napló, 1870. július 9. (szombat), 1. A replikát megelőző szerzői instrukció Anna csaknem hisztérikus felindultságára utal: „Kitöréssel.”
} 
Anna először Althán, majd a király becsületének megmentésére apellál, mint aminek biztosítéka lehetne, ha Althán a királyi parancs ellenében hazahozná a királynét. ${ }^{80}$ Férj és feleség szóváltásában ezen a ponton avatkozik be Irén, és az érvekböl kifogyó, az önleleplezés határára jutó Anna segítségére siet: „Saját szeszélyei dacára: mondom én, / És Anna kéri önt. Mi elhatározók, / Hogy a királyi férj mellett legyen neje, / Károly uralkodó családunk zárja be. / Ha férfi ivadék nincs, hogy kövesse őt / A trónra. (Annához súgva:) (Te is csak azt/Beszéld.)"'11 Vagyis Irén megmentő (bár kérdéses, mennyiben kegyes) hazugságként áll elő egy váratlan érvvel, amely arra a dinasztikus problémára utal, amelyet a titkos családi szerződés, majd nyilvános megerősítése meg kívánt oldani. Irén gyors közbeavatkozása azt a célt szolgálja, hogy egy hihető, nyomós és visszautasíthatatlan érvvel leplezze el Anna kérésének valós indokait. Kemény nyelvi - és ettől nem függetlenül drámai - ereje éppen ezen a ponton mutatkozik meg a leginkább. A szituáció ugyanis akár vígjátéki alaphelyzetként is kidolgozható volna, bohózatba illö is lehetne. A gyanútlan, mit sem sejtő férj, akit a királyi szerető éppen halálos küldetéssel indít útjára, részint hogy megtorolja a hiúságán esett sérelmet, részint hogy fájdalmat okozzon a férjhez visszatérni akaró asszonynak, részint hogy eltávolítsa az útból riválisát. A könyörgő feleség, aki azt kéri a felszarvazott férjtől, hogy hozza vissza elhagyott szeretője feleségét, részint hogy megtorolja Károly lépését, részint hogy fájdalmat okozzon a megunt szeretőnek, részint hogy útját állja a király további ostromának, és nem utolsó sorban, hogy saját magát megóvja a kísértéstől. És ezen a ponton kerül elő Irén arzenáljából a támadhatatlan érv. Kemény töredéke, dramolettként olvasva, mégsem fullad bohózatba. Mindenekelött Anna karakterének lélektani kidolgozottsága, és nem a dikciónak emelkedettséget kölcsönző drámai jambus okán.

A közel ezersoros verses dialógusszöveg majdnem fele Anna beszéde, ${ }^{82}$ a két hoszszabb és a néhány soros záró monológ kellő teret kínál a centrális alak kidolgozásához. Anna az egyetlen szereplö, aki mindvégig a színen van, az Irénnel, majd Károllyal és végül Althánnal közös jelenetek (kvázi duettek) lehetőséget kínálnak egy bonyolult személyiség kiépítésére. Anna válságának és önértésének alakulását a három beszélgetötárssal folytatott dialógus három stációként mutatja. Az elsőben Irén, a segitő, egyfajta tükörfelület, akinek jelenléte azt szolgálja, hogy Anna saját maga számára is megfogalmazhassa, megoszthatóvá és így megérthetővé tegye a belső, affektív történéseket. Nem

\footnotetext{
${ }^{80}$ Anna: Könyekbe lábbadó szemem kér, hozd el őt.

Althán: Igérni nem merem, nem a veszély miatt, / Hisz életem, melyet szeretni most tudok, / Örömmel áldozom éretted, Anna, föl, / Ki megismertetéd becsét... A mai nap / Díjául kérheted halálomat. E díj / Nem éri föl, a mit cserében nyertem én. / ...De a becsületem...

Anna: (Szenvedéllyel.) Azt mentsd meg férjem, azt! $[\ldots]$

Anna: [...] Óh védd meg a király becsületét, Althán, / Saját... (Szava elakad, térdei reszketnek.) Uo., 2. ${ }^{81}$ Uo.

${ }^{82}$ Vagyis a dramolett terjedelme negyede a Tragédiáénak: ebből Anna szólamához, aki végig a színen van, 470 sor tartozik, ebből három monológ (egy 57 sors, egy 78 soros, és a hatsoros zárlat).
} 
véletlen, hogy a Károllyal folytatott dialógus epizódként és jelentként is kikülönül: vetélkedés, amely joggal idézi fel az olvasóban a haláltáncok hangulatát. Ebben az epizódban Anna a középpontos drámák (Bécsy Tamás) hőseit idézi, hiszen a királlyal szemben eszköztelen, sorsa a király kezében van, csupán meggyőzheti, de le semmiképpen nem. A három partner közül a legfontosabb Althán. ${ }^{83}$ Anna karakterének összetettsége valójában ebben a szituációban mutatkozik meg a leginkább: tragikus hőssé is ebben a helyzetben válhat, emberi esendőségében, hiszen olyan indulatok és érzelmek irányítják, amelyeknek nem lehetséges egyidejüleg megfelelően cselekedni. Kemény hősnője úgy válik összeomlásában és szánalmas diadalában egy antik tragédia szereplöjévé, hogy sem a bünt, sem a bünbánatot nem képes felvállalni. A mai olvasó számára talán ezért tünhet menthetetlenül modern antihősnek.

\section{Ágnes Hansági}

Zsigmond Kemény, die politische Tageszeitung Pesti Napló, die „Lust zum Lesen” und eine Menschheitsdichtung

Der Schriftsteller Zsigmond Kemény war anderthalb Jahrzehnte lang Chefredakteur der Pesti Napló und dank seiner Tätigkeit wurde die politische Tageszeitung zum einflussreichsten ungarischen Presseorgan. Von 1852 bis 1853 veröffentlichte Kemény in diesem Blatt seine programmatische Bildungskonzeption in Fortsetzungen. Im Mittelpunkt stand dabei das Lesen als eine Entwicklungs- und sogar als eine Demokratiefrage. Obwohl seiner Ansicht nach die wichtigste Aufgabe der damaligen ungarischen Presse darin bestand, Menschen zum Lesen anzuregen, verdrängte er später allmählich Feuilleton und Belletristik aus der Tageszeitung, nachdem er im Juni 1855 die Redaktion übernommen hatte. Das Massenblatt, das bis dahin auf drei Programmbereichen fundierte, wurde nun in eine Plattform verwandelt, die sich an eine geschlossene politische Öffentlichkeit richtete. Diese Neugestaltung war ein entscheidender Beitrag zur erfolgreichen Verwirklichung jener politischen Ziele, die im Österreichisch-Ungarischen Ausgleich (1867) verankert waren. Vor diesem Hintergrund lässt sich die Menschheitsdichtung „Anna”, die nach dem Ausgleich in sechs Fortsetzungen veröffentlicht wurde, als symbolisch interpretieren.

\footnotetext{
${ }^{83}$ Irén szólama 130 sor, Károlyé 136, Altháné 183, vagyis Anna után ő a dramolett második legfontosabb figurája.
} 